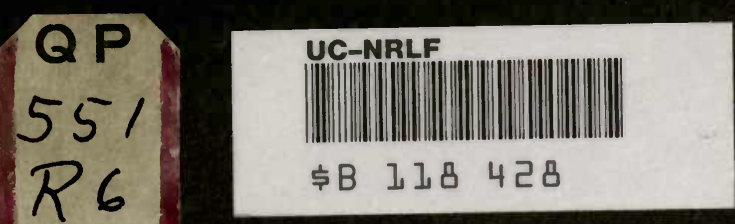




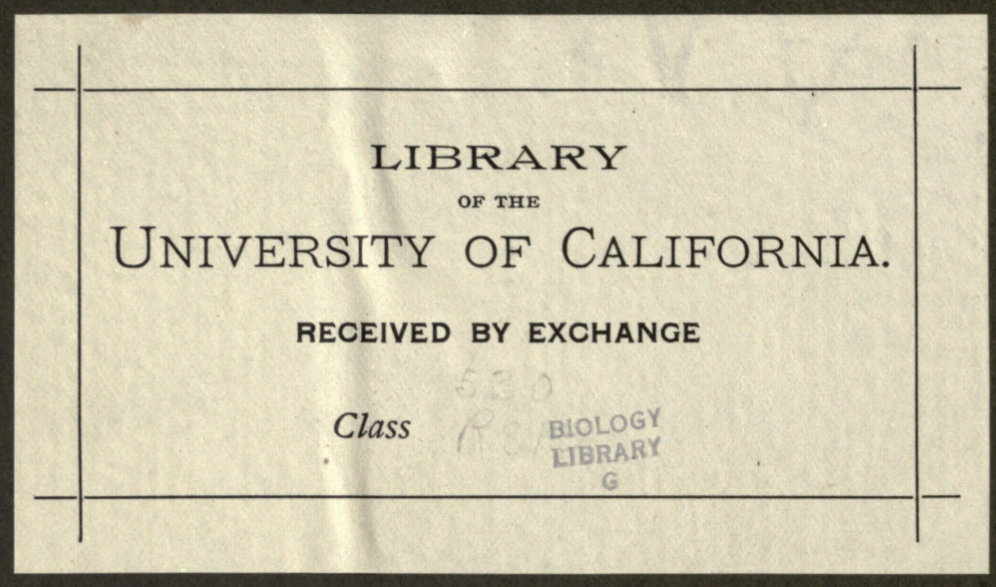




\section{A Contribution to the Study of the Nature and Origin of the Bence Jones Protein}

\section{DISSERTATION}

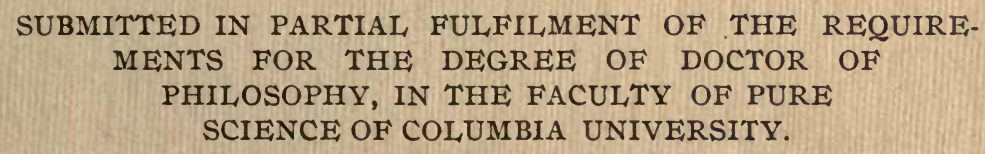

SUBMITTED IN PARTIAL FULFILMENT OF THE REQUIREMENTS FOR THE DEGREE OF DOCTOR OF PHILOSOPHY, IN THE FACULTY OF PURE SCIENCE OF COLUMBIA UNIVERSITY.

\section{BV \\ JACOB ROSENBLOOM, B.S.}

NEW YORK CITY

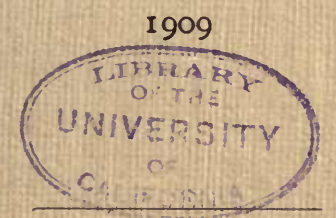

EASTON, PA.

ESChENBACH PRINTING COMPANY.

Igog. 
$\sum$ 


\section{A Contribution to the Study of the Nature and Origin of the Bence Jones Protein}

\section{DISSERTATION}

SUBMITTED IN PARTIAL FULFILMENT OF THE REQUIREMENTS FOR THE DEGREE OF DOCTOR OF PHILOSOPHY, IN THE FACULTY OF PURE SCIENCE OF COLUMBIA UNIVERSITY.

BY

JACOB ROSENBLOOM, B.S.

NEW YORK CITY

I 909

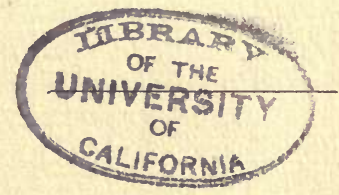

Easton, Pa.

Eschendach Printing Company.

Igog. 
ato $\frac{2}{R 6}$ 


\section{CONTENTS.}

Page.

I. Introduction. $\ldots \ldots \ldots \ldots \ldots \ldots \ldots \ldots \ldots \ldots \ldots \ldots \ldots, \quad 7$

II. Historical. ......................... 8

III. Proteosuria and the Bence Jones protein............. 10

IV. Theories as to the formation or nature of the Bence Jones

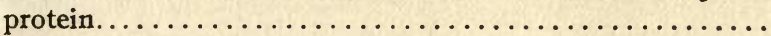

V. The Bence Jones protein and multiple myeloma, myelopathic proteosuria (Kahler's disease)................. $1_{3}$

VI. Experimental.

A. On the preparation of digestive products of osseoalbumoid.. 15

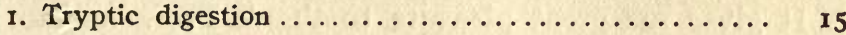

2. Peptic digestion......................... I6

3. Summary of results of procedures $A(I-2) \ldots \ldots \ldots \ldots$ 2I

B. Subcutaneous injection of products of the peptic digestion of

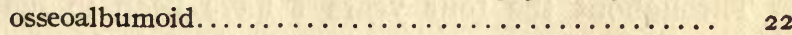

1. First experiment..................... 23

2. Second experiment..................... 26

3. Third experiment.................... 28

C. Subcutaneous injection of products of the tryptic digestion

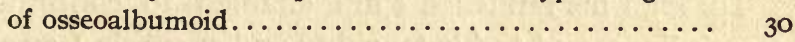

Summary of results of procedures B-C......... 34

D. Leucocytic proteolysis of osseoalbumoid............. 35

Summary of results of procedure D........... 37

E. Subcutaneous injection of products obtained in the leucocytic proteolysis of osseoalbumoid............... 38

F. Intravenous injection of products obtained in the leucocytic proteolysis of osseoalbumoid............... 40

I. First experiment .................... 40

2. Second experiment.................... 40

3. Summary of results of procedures E-F......... 44

G. Intraperitoneal injection of osseoalbumoid........... 44

H. Intrapleural injection of osseoalbumoid............ 45

Summary of results of procedures G-H........ 47

VII. Summary of general conclusions............... 47

VIII. Bibliography......................... 49

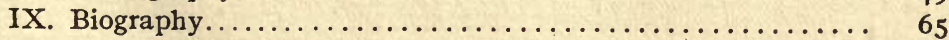

X. Publication.............................. 66 


\section{ACKNOWLEDGMENT.}

It gives me great pleasure to thank Prof. William J. Gies for suggesting this problem and for his constant supervision of the work.

Throughout the four years I lave been in his laboratory he has been ever ready to give me the benefit of his time and wide knowledge, notwithstanding the pressure under which he has to work.

Through his influence I am enabled to continue along research lines, and to his teaching and example I owe whatever I may be able to produce as a contribution to Experimental Medicine.

LABORATORY OF BIOLOGICAL CHEMISTRY OF

COLUMBIA UNIVERSITY, AT THE

Colzege of Phystcians

$\triangle N D$ SUXGEONS,

NEW YORK.

May, Igog. 


\section{DEDICATION.}

Inscribed to my first Professor of Chemistry Francis Clifford Phillits as a slight token of my esteem. 



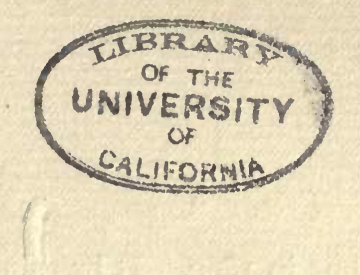

\section{INTRODUCTION.}

This study is a continuation of the preliminary work by Ottenberg and Gies who found in this laboratory that crude elastose, after its subcutaneous or intraperitoneal injection, can readily be detected in the urine by the heat precipitation test. Since the Bence Jones protein has various properties in common with elastoses, Ottenberg and Gies suggested that osseoalbumoid (bone elastin?) might be the forerunner of the Bence Jones protein, which appears in the urine of people with multiple myeloma of the bones.

It was thought that perhaps the osseoalbumoid of the bone might be so acted upon by the enzymes present in the cells of the myelomatous growth, as to give rise to a body having the properties of the Bence Jones protein.

\section{HISTORICAL.}

It was the writer's intention before beginning his study of the literature of the Bence Jones protein and multiple myeloma, to make a list of all the known cases of myeloma and Bence Jones albuminuria, with the characteristics of each, but this was found to have been done by Anders and Boston, who record cases up to 1903 and give a report of three new cases; by Weber, who records 28 cases up to 1904 and gives the history of ten more cases; by Moffat, who records 39 cases up to 1905; and by Permin, who records 40 cases up to 1907. Decastello in a recent paper gives a description of two more cases and an analysis of the previously recorded cases.

In 1847 Bence Jones presented before the Royal Society of London, a paper "On a New Substance Occurring in the Urine of a Patient with 'Mollities Ossium,' ". in which he described, for the first time, the substance since known as the Bence Jones protein. In the Philosophical Transactions of the Royal Society (1848, i, p. 55) he described several properties of this body, and gave his results of a study of it in his case of Mollities Ossium. The Bence Jones protein was rediscovered 
and described by Kühne in I869. It has since been the subject of many investigations, especially by Matthes, Ellinger, Magnus-Levy, Jochman and Schumm, Bradshaw, Park, Moffat, Simon, and others.

Ellinger succeeded in obtaining the Bence Jones protein in small amounts from diseased bone marrow and ascitic fluid. Virchow found it in the bone marrow in cases of osteomalacia, so called. Barr could not find in the bone marrow or bone tumor substance, any trace of the Bence Jones protein or of enzymes. Wood claims to have separated the Bence Jones protein from a portion of bone affected by multiple myeloma, but could not obtain it from the bone marrow in any other portion of the body of the patient. Askanazy was able to demonstrate its presence in the bone marrow of a case of multiple myeloma but was unable to find it in the blood from this patient. Löwy could not detect a trace of the Bence Jones protein in the marrow of the affected ribs and humerus of Kalischer's case. Weber, however, was able to prove the presence of a substance giving reactions similar to those of the Bence Jones protein, in the vertebrae and ends of the femur in a case of multiple myeloma, but he could not detect this substance in any organ or tissue. Bruce, Lund, and Whitcomb found, in a case of multiple myeloma, that the fluid obtained from an affected bone, after sawing through it, gave the reactions of the Bence Jones protein. Ribbinik could not find the Bence Jones protein in the bone marrow substance of the case studied by him. Fleischer, however, has found a substance giving the reactions of the Bence Jones protein in normal bone marrow.

Bradshaw and Warrington, in an analysis of a rib affected with multiple myeloma, found the relation of organic and inorganic substances to be practically normal. Magnus-Levy and also Grutternick and deGraaf have succeeded in obtaining the Bence Jones protein in crystalline form.

Moitessier on subjecting the Bence Jones protein to gastric digestion obtained acidalbumin, primary proteoses (except heteroproteose), secondary proteoses and peptone. After peptic digestion of the Bence Jones protein, Simon could not 
detect primary proteoses, among the products formed, but found deuteroproteose "B" (Pick) and peptone "A" (Pick).

Magnus-Levy published results of a study of the digestiveproducts of the Bence Jones protein, its reactions and content of amid, diamino and monamino nitrogen. Huppert records results of various elementary analyses that have been made of the Bence Jones protein. Abderhalden and Rostoski made an analysis of the Bence Jones protein with regard to its content of the amounts of the various amino acids. Reach gives the results of an analysis of the Bence Jones protein in terms of its nitrogen partition.

Zuelzer obtained the Bence Jones protein in the urine of dogs poisoned with pyrodin (monoacetyl-phenylhydrazine), a strong hemolytic agent. Stokvis found the Bence Jones protein in the urine of dogs after its intravenous or rectal injection. Matthes also found it in the urine of a dog after the subcutaneous injection of the Bence Jones protein. Ellinger introduced 5 grams of the Bence Jones protein intravenously in a dog but the urine yielded no precipitate with $\left(\mathrm{NH}_{4}\right)_{2} \mathrm{SO}_{4}$, although the filtrate gave a strong biuret reaction suggestive of peptone (Kühne), which may have been derived from the injected material.

Allard and Weber found that the Roentgen ray treatment of the bone tumor had no effect on the urinary output of the Bence Jones protein. Voit and Salvendi report a case in which diet modified the elimination of the Bence Jones protein, but Weber found that changes of diet had no influence on its elimination in his case of multiple myeloma.

Ribbinik and Askanazy could not find the Bence Jones protein in the blood of a patient with multiple myeloma. Coriat found the Bence Jones protein in a pleural effusion in a patient suffering from multiple neuritis associated with extreme tenderness of the ribs, while it was absent from the urine. He found that on tryptic digestion it went into complete solution.

In a case of Weber's, microscopic section of some of the organs showed the presence of a homogeneous hyaline substance which he thought might possibly be the Bence Jones protein. 
Rostoski found that the method of "precipitin" detection fails to distinguish the Bence Jones protein from various proteins of human origin.

\section{PROTEOSURIA AND THE BENCE JONES PROTEIN.}

Proteoses have been found in the urine in many conditions, usually in minute quantities and as temporary constituents of the urine during the course of specific fevers, inflammatory processes and other diseases. The urinary proteoses present different characteristics from those of the Bence Jones protein, however, and must be sharply distinguished from the latter. Among the most prominent of these differences between the Bence Jones protein and the ordinary proteoses, the following may be indicated in terms of the Bence Jones protein:

I. Soluble in water (different from heteroproteose).

2. Coagulated at low temperatures (unlike other proteoses collectively), though elastoses are precipitated by heating their aqueous solutions but redissolve as the temperature falls.

3. Convertible into acid and alkali albuminates (unlike other proteoses collectively).

4. Digested by pepsin- $\mathrm{HCl}$, yields primary proteoses except heteroproteose (unlike protoproteose).

5. Not acted upon by erepsin (different from the primary proteoses).

6. Excreted in larger quantities than the proteoses.

7. Does not dialyze through parchment membrane (different from all soluble proteoses).

8. Not precipitated from a saline solution on dialysis (different from many proteoses).

9. It is crystallizable (different from all proteoses).

\section{THEORIES AS TO THE FORMATION OR NATURE OF THE BENCE JONES PROTEIN.}

Kühne believed the Bence Jones protein to be closely related to heteroproteose on account of the fact that the pure substance, after its precipitation from its solution by heating, is redissolved on further raising the temperature. Huppert 
also thinks the protein is a heteroproteose. Dechaunne considers it to be a mixture of at least three proteins or groups of proteins, probably proto and dysproteoses and a substance like heteroproteoses. Neumeister showed that the Bence Jones protein is not heteroproteose and did not believe that there was any relation between digestion and the presence of this substance in the urine. He thought, rather, that it is a substance of a peculiar kind and quite unlike any other that had hitherto been described. Matthes was of the same opinion as Neumeister.

Simon thinks the Bence Jones protein is formed from the serum globulins, perhaps by an enzymotic action of the tumor cells, and that once formed it is rapidly excreted by the kidney as are all foreign proteins. Kühne and Chittenden found that, on the basis of elementary composition, the Bence Jones protein resembled heteroglobulose and they also suggest that it may arise from serum globulin. Coriat also thinks it might be formed from serum globulin. He supposes it is formed by the digestive action of leucocytes or bacteria, or more particularly, from the enzymotic action of plasma cells of the bone marrow. Donetti believes that it results from some loss of function of the bone marrow, owing to the destruction of the latter.

Weber and Hutchison concluded that the Bence Jones protein is formed from granules found in the myelomatous cells. Virchow believed the substance resulted from degenerative changes in protein occurring in sarcomata. Weber also thinks it may be due to an abnormal metabolic or degenerative process in the myelocytes, or in the tumor cells derived from the myelocytes or their predecessors. Von Rustizky likewise considered that the substance is produced in connection with the new bone growth. Moitessier believed it is formed by a modification of the albumoids of the blood plasma brought about by the new growth. In a recent paper Weber and Leginham, on account of the histological evidence in the case of multiple myeloma studied by them, think that the cytoplasmic residua of karyolyzed plasma cells may be the source of the Bence Jones protein. 
Senator and Noel-Paton incline to the view that the Bence Jones protein represents an abnormal product of the metabolism of the protein of the food. Magnus-Levy also thinks it is formed from the food proteins as a result of altered protein metabolism, because as much as $30-70$ grams of the substance per day may be excreted whereas the total amount of protein in all the tumor tissue seldom exceeds, or indeed, equals this quantity, and he considers it impossible that so little tumor tissue can form so much urinary protein.

Lindeman believes that, while the Bence Jones protein cannot be put in any group of proteins, it is nearest in structure to the true albumins. Abderhalden states that, judging from the yield of amino acids from the Bence Jones protein, the latter does not correspond to either of the two serum proteins, but may be considered as one of the tissue albumins, which without being broken down or changed into one of the serum albumins, is transmitted to the blood and is then probably eliminated as an albumin foreign to the blood although suited to the needs of the body.

There is also the possibility that multiple myeloma might be due to a specific bacillus, which by the action of its toxins so alters the normal changes occurring in bone marrow as to form this substance from the tissue protein. This idea is strengthened by the analogy Weber has drawn between the characteristics of multiple myeloma and mycosis fungoides, which is thought by some to belong to the group of infective granulomata. Another idea that might be held as to its mode of formation is the following: Possibly the columnar epithelium that lines the alimentary canal is diseased, the agent that converts the digestive products may therefore fail to functionate and, in consequence, the incompletely synthesized products are taken into the blood stream and then eliminated as matter foreign to it. This does not seem probable on account of the fact that in cholera, when marked changes are present in the columnar epithelium, the Bence Jones protein is not excreted, although, of course, in cholera the said changes may be insufficient in kind or degree to produce the result. 


\section{THE BENCE JONES PROTEIN AND MULTIPLE MYELOMA, MYELOPATHIC PROTEOSURIA (KAH- LER'S DISEASE).}

In I889 Kahler and Huppert reported a case of multiple myeloma from clinical and chemical standpoints, respectively, and in 1897 Bozzola reported a case under the title of "Sulla Malattia di Kahler" thus recognizing Kahler as the first to show the relationship between proteosuria and primary bone disease. These lesions, however, were classified in 1873 as myeloma by Von Rustizky.

Careful study of cases where the Bence Jones protein was excreted shows that there must certainly be some relation between the excretion of the Bence Jones protein and diseased conditions of the bones of the patient. Although we cannot say that the Bence Jones protein is peculiar to the growth known as multiple myeloma, ${ }^{1}$ it is certain that the Bence Jones protein is present in the urine in 80 per cent. of the cases exhibiting this condition. In cases of excretion of the Bence Jones protein unaccompanied by multiple myeloma, disease of the blood-forming organs or of bone was present.

Weinberger found the Bence Jones protein in the urine from a case of chloroma; Vidal in a case of tuberculous osteoarthritis; Kahler in primary lympho-sarcoma of the spinal cord; Oerum in a case where the bone tumors were multiple metastases of a gastric carcinoma; Kottnitz and Von Noorden in cases of leukaemia. The case of osteomalacia, reported by Jochman and Schumm, was subsequently shown to be one of multiple myeloma, and that of Askanazy reported as one of lymphatic leukaemia was undoubtedly one of multiple myeloma. However, Von Jaksch and also Fitz have shown that proteosuria (so-called) may be a marked feature of myx-

${ }^{1}$ Various names applied to multiple myeloma: Myeloma multiplex (Rustizky), sarcoma multiplex ossium (Buch), pseudoleucaemia myelogenes (Runeberg), osteomyelitis maligna (Grawitz), ostitis sarcomatosa (Hammer), endothelioma intravascular (Marckwald), lymphosarcoma multiplex ossium (Wieland), myelosarcoma (Schmaus), lymphadenia ossium (Nothnagel), erythroblastoma (Ribbert), plasmoma malignum (Hoffman). 
edema. Collins reported a case of undoubted multiple myeloma that was observed for several months and in which there was no excretion of the Bence Jones protein. Naunyn reported a case in which the whole skeleton was riddled with metastatic carcinomatous growths and the urine examined for the Bence Jones protein for some time, but it was never present. Scheele and Herxheimer reported a case of multiple myeloma with no Bence Jones protein in the urine.

The above-mentioned case of Naunyn's may be explained according to Weber as follows: the tumor cells derived from bone marrow cells, however much they may resemble morphologically true bone marrow cells, are more prone to abnormality (including unusual degenerative changes) than real myelocytes. Furthermore, metastatic tumors in the bone marrow do not give rise to the Bence Jones protein for the reason that nonmyelogenic tumor cells are not affected in the same way.

The view of Decastello that the Bence Jones protein is only excreted in those cases where the kidneys are diseased, is hard to reconcile with the statement of others that the serum proteins are never, and of some investigators that they are seldom, excreted together with the Bence Jones protein. One would think that if the kidneys are diseased, albuminuria would occur in a larger proportion of cases. The Bence Jones protein is excreted in 80 per cent. of the cases of multiple myeloma, but it does not appear likely that so many would present kidney lesions. It seems more likely that the kidney lesion is a result of the excretion of the Bence Jones protein rather than the cause of its elimination, especially since Stokvis has shown that hemiproteose solution injected under the skin once or twice, will pass out through the kidneys without doing them any apparent injury, but if the injections are frequently repeated, the hemiproteose in passing through the kidneys appears to excite in them organic disease.

\section{EXPERIMENTAL.}

At the outset of this study it was necessary to ascertain whether osseoalbumoid is digestible, $i$. e., whether proteases convert it into familiar types of hydration products. Further, 
it was necessary to determine whether any osseoalbumoses that might thus be produced would behave like elastoses when their aqueous solutions are heated. In all of these experiments the osseoalbumoid employed was made by the Hawk and Gies method. ${ }^{1}$

A. On the Preparation of Digestive Products of OsSEOALBUMOID. I. Tryptic Digestion. a.-A small quantity of osseoalbumoid, which had been made in a preliminary way, ${ }^{2}$ was subjected to the action of a strong, alkaline tryptic solution for 24 hours at $40^{\circ} \mathrm{C}$. The true osseoalbumoid in the preparation was completely digested by that time. Proteoses were formed. A small amount of admixed collagen remained undigested. The whole of this collaginous residue was readily converted into gelatin.

b. After 5 hours' digestion of fresh osseoalbumoid ${ }^{3}$ in $80 \mathrm{cc}$. of 0.25 per cent. $\mathrm{Na}_{2} \mathrm{CO}_{3}$, containing 0.5 gram of trypsin (Merck), the mixture was filtered and the filtrate saturated with $\left(\mathrm{NH}_{4}\right)_{2} \mathrm{SO}_{4}$ at the boiling temperature. During the digestive process samples of the solution were withdrawn at intervals of 45 minutes and when examined gave negative results in the heat-precipitation test.

The $\left(\mathrm{NH}_{4}\right)_{2} \mathrm{SO}_{4} \mathrm{ppt}$. was dissolved in water, dialyzed until free from sulphate and evaporated to dryness at $40^{\circ} \mathrm{C}$. on a water bath. The residue after 5 hours' digestion was subjected to the action of a fresh trypsin solution and allowed to digest for 18 hours longer, then treated by the process described above.

c. A sample of the original ossein shavings was subjected to the influence of a very active tryptic solution but the shavings were unaffected. The filtrate from the unchanged bone shavings was tested with fibrin as to its digestive power and found to be active. A repetition of this experiment yielded the same negative result.

${ }^{1}$ Hawk and Gies: American Journal of Physiology, 1902, vii, p. 340; also, Gies and collaborators: Biochemical Researches, 1903, i, p. I8I (Reprint No. 6).

2 From ossein shavings prepared in 1900 and kept dry meanwhile.

${ }^{3}$ Made from a portion of the same ossein shavings (a). 
2. Peptic Digestion. a.-A small quantity of osseoalbumoid was treated with I liter of 0.2 per cent. $\mathrm{HCl}$ containing 0.1 per cent. of pepsin (P. D. \& Co. $1: 2000$ ) in an incubator at $40^{\circ} \mathrm{C}$. Portions of the digestive fluid were withdrawn at intervals and heated gradually to boiling. Digestion was started at 2.30 P.M. The following notes were recorded in connection, especially, with the treatment of filtered portions of the digestive fluid:

3.00 P.M. No precipitate on heating.

\begin{tabular}{|c|c|c|c|c|}
\hline 3.30 & 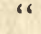 & 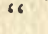 & 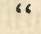 & 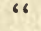 \\
\hline 4.00 & “ & “ & “ & “ \\
\hline 4.20 & “ & "“ & “ & " \\
\hline $4 \cdot 30$ & "“ & " & “" & “" \\
\hline $4 \cdot 45$ & ““ & “" & “" & “" \\
\hline $\begin{array}{l}5.00 \\
5.20\end{array}$ & “ & ، & “ & “ \\
\hline $5 \cdot 30$ & “ & “ & “ & " \\
\hline
\end{tabular}

Material gradually disappearing. Pepsin added, 0.25 gram.

Some undigested material still present.

Small amount of material undigested.

The undigested material was filtered off and the boiling filtrate nearly saturated with $\left(\mathrm{NH}_{4}\right)_{2} \mathrm{SO}_{4}$. Proteoses were separated as a dark scum on the surface of the solution. The precipitate dissolved readily in warm water. This solution was not precipitated by heat, even after dilution. The solution was speedily evaporated to dryness at $40^{\circ} \mathrm{C}$. and in the dry state looked like scale gelatin.

The incompletely saturated filtrate from the proteoses was treated with sufficient $\left(\mathrm{NH}_{4}\right)_{2} \mathrm{SO}_{4}$ to effect complete saturation and a small amount of a dark sticky material was precipitated, which dissolved readily in warm water but gave no turbidity on heating.

$a^{\prime}$. In the preparation of osseoalbumoid the last portions of admixed collagen are difficult to remove. In the peptic digestion of osseoalbumoid admixed with collagen, the latter is gelatinized and then converted into gelatoses and gelatin peptones. It was thought that possibly such gelatin or its hydration products might have been admixed with the osseoalbumoses obtained in the preceding experiments and that, by its presence, might have prevented the occurrence of the elastose-like reaction on heating. Consequently a portion 
of the osseoalbumoid employed in the preceding digestion experiment was treated from time to time with boiling water until no more collagen or gelatin could be present, as indicated by practically complete absence of protein from the washings. The small quantity of osseoalbumoid that remained was filtered off, washed with water and subjected to peptic digestion in $\mathrm{I} / 2$ liter of 0.2 per cent. $\mathrm{HCl}$ containing $0.25 \mathrm{gram}$ of pepsin (P. D. \& Co. $\mathrm{x}: 4000$ ) and placed in an incubator at $40^{\circ}$ C. at 2.25 P.M.

2.35. No precipitate appeared on heating a filtered sample of the digestive fluid.

2.50. A precipitate was obtained on heating, which almost completely dissolved on further heating. It reappeared on cooling and was as marked a precipitate as that obtained on the first application of heat.

The remainder of the peptic mixture, after digesting for 2 hours and ro minutes, was filtered and the hot filtrate treated with $\left(\mathrm{NH}_{4}\right)_{2} \mathrm{SO}_{4}$. A flaky precipitate was produced before the solution was completely saturated with $\left(\mathrm{NH}_{4}\right)_{2} \mathrm{SO}_{4}$ and at a temperature of about $65^{\circ} \mathrm{C}$. Most of the precipitate was soluble in water.

The small amount of undigested matter which was obtained after filtering was further digested. To the filtrate, after the digestion of this product for 3 hours, was added $\left(\mathrm{NH}_{4}\right)_{2} \mathrm{SO}_{4}$ to saturation.

The substance precipitated by $\left(\mathrm{NH}_{4}\right)_{2} \mathrm{SO}_{4}$ had the following properties:

(I) The reaction of its solution was acid $(\mathrm{HCl})$.

(2) On heating this solution a precipitate was produced which dissolved on further heating and, on cooling, reappeared. Heated again, the same reactions were obtained, but after a third heating of this solution, the precipitate did not entirely disappear on boiling.

(3) Duplication with another sample of the treatment just described (2) led to immediate precipitation on heating but boiling did not entirely clarify. On cooling, however, the precipitate was more marked than before. 
(4) A portion of the solution was neutralized. Heating failed to produce a precipitate in it.

(5) The same negative result (4) was obtained with the alkalized solution.

(6) After diluting the original solution, no precipitate was formed on heating.

(7) A bulky white flocculent precipitate was formed when the solution was added to alcohol (sulphates?). A solution of this precipitate gave no precipitate on heating.

The elastose-like precipitation that ensued on heating the acid solution $(2,3)$ led to the conclusion that possibly the result was due to a constituent of the pepsin. Accordingly, a solution was made of pepsin in 0.2 per cent. $\mathrm{HCl}$ and, on heating, a faint clouding of the solution took place, but without further change on boiling or on subsequent cooling.

Saturation of this peptic solution with $\left(\mathrm{NH}_{4}\right)_{2} \mathrm{SO}_{4}$ failed to yield an appreciable precipitate.

b. Pure osseoalbumoid was treated with I liter of 0.2 per cent. $\mathrm{HCl}$ containing 0.5 gram of pepsin (P. D. \& Co. $\mathrm{r}: 4000$ ) and placed in an incubator at $35^{\circ} \mathrm{C}$. at I I.05 A.M.

Ir.45 Most of the material had disappeared into solution. Some of the liquid was withdrawn and, on adding $\left(\mathrm{NH}_{4}\right)_{2} \mathrm{SO}_{4}$ with very little heating, a dark substance was precipitated, which proved to be insoluble in water, and was returned to the digestive mixture.

12.00 About $15 \mathrm{cc}$. of the fluid were withdrawn, filtered, and the filtrate saturated with $\left(\mathrm{NH}_{4}\right)_{2} \mathrm{SO}_{4}$ in the cold. A white flaky material was precipitated, which was readily soluble in water, but on heating this solution no precipitate was formed.

A sample of the pure pepsin-acid solution, which was used in the foregoing experiment, was saturated with $\left(\mathrm{NH}_{4}\right)_{2} \mathrm{SO}_{4}$. A very slight amount of precipitate was formed which dissolved in water but gave no precipitate on heating.

The remainder of the solution of the $\left(\mathrm{NH}_{4}\right)_{2} \mathrm{SO}_{4}$ precipitate was dialyzed till free from sulphate and then evaporated to dryness on a water bath at $40^{\circ} \mathrm{C}$. The dialyzate contained 
very little protein as was shown by the practically negative response to the biuret test.

c. Osseoalbumoid was prepared as before. An attempt was made to obtain a product at an earlier stage in the preparation process than that of the preceding experiment. The product had the same fluffy characteristic as before, only it had a blood-red color.

This crude osseoalbumoid was subjected to the peptic conditions of the previous experiment. Digestion was started at 9.45 A.M.

I0.35 A.M. Heating a portion of the filtered digestive liquid failed to cause turbidity in it.

I0.5O A.M. Heating a portion of the filtered digestive liquid failed to cause turbidity in it.

II.O5 A.M. A portion of the digestive fluid was withdrawn and saturated with $\left(\mathrm{NH}_{4}\right)_{2} \mathrm{SO}_{4}$ in the cold. A yellow sticky precipitate was formed. It was completely soluble in warm water. No precipitate was formed on heating this solution. A portion of the solution was saturated with $\left(\mathrm{NH}_{4}\right)_{2} \mathrm{SO}_{4}$ at the boiling temperature. A precipitate was formed, which was soluble in water but gave no precipitate on heating.

II.30 A.M. About $\mathrm{I} / 8$ of the original bulk of material remained undigested. It was filtered off and subjected to the action of a fresh pepsin-acid solution.

This residue did not, however, undergo digestion on further treatment with pepsin- $\mathrm{HCl}$ and looked like hematin. It was soluble in $\mathrm{Na}_{2} \mathrm{CO}_{3}$ from which solution it could be precipitated by acidifying. Its solution gave the spectroscopic lines of acid hematin.

The filtrate from the undigested material was saturated with $\left(\mathrm{NH}_{4}\right)_{2} \mathrm{SO}_{4}$ in the cold. The precipitate had a reddish color. The filtrate from this precipitate was saturated with $\left(\mathrm{NH}_{4}\right)_{2} \mathrm{SO}_{4}$ at the boiling temperature. Each of these precipitates was dissolved in water. Samples of the solutions were gradually heated with the results indicated in the summary on the next page. 
Solution in water (acid)

" made neutral

" made alkaline

" diluted
Pp't. produced in

the cold.

No pp't.

“

6
Ppt. produced at the boiling temp.

No pp't.

The remainders of the solutions of these precipitates were dialyzed free from sulphate and speedily evaporated to dryness on a water bath at $40^{\circ} \mathrm{C}$. The dialyzates contained little or no protein, as shown by the practically negative results with the biuret test.

$d$. Osseoalbumoid was subjected to peptic digestion. It was placed in an incubator at 9.15 A.M. and at 12.15, one-half of the digestive solution was removed and precipitated by saturation in the cold with $\left(\mathrm{NH}_{4}\right)_{2} \mathrm{SO}_{4}$, after careful neutralization with $\mathrm{NaOH}$. At the point of neutralization a voluminous precipitate was obtained which was filtered off and, upon testing, found to be easily soluble in dilute $\mathrm{HNO}_{3}$, to give a yellow precipitate with ammonium molybdate and no protein reactions. It was thought, therefore, that this precipitate consisted of phosphates that had not been removed by the acid treatment of the original ossein shavings.

The $\left(\mathrm{NH}_{4}\right)_{2} \mathrm{SO}_{4}$ precipitate produced by saturation at room temperature was filtered off and the filtrate saturated with $\left(\mathrm{NH}_{4}\right)_{2} \mathrm{SO}_{4}$ at the boiling temperature. An aqueous solution of these products did not yield a heat precipitation test.

The remaining half of the digestive mixture, after $81 / 2$ hours' digestion, was filtered, the filtrate neutralized, the phosphates filtered off and $\left(\mathrm{NH}_{4}\right)_{2} \mathrm{SO}_{4}$ added to saturation, as in the treatment of the first half.

A considerable amount of solid substance remained at the end of the digestive treatment. This was subjected to peptic digestion for 24 hours longer (a total of 32 hours) and then filtered and treated by the $\left(\mathrm{NH}_{4}\right)_{2} \mathrm{SO}_{4}$ process described above.

Each of the precipitates was dissolved in water, dialyzed till free from sulphate and speedily evaporated to dryness at $40^{\circ} \mathrm{C}$.

$e$. Fresh ox-femurs were used and osseoalbumoid was 
isolated from the hashed ossein shavings as in experiments $a-d$.

A portion of the product was subjected to peptic digestion as in the previous experiments $(a-d)$, and after four hours' digestion, the mixture was filtered and the filtrate neutralized with $\mathrm{NaOH}$. The precipitated phosphates were removed by filtration and the remaining solution saturated with $\left(\mathrm{NH}_{4}\right)_{2} \mathrm{SO}_{4}$ at the boiling temperature.

The precipitate obtained by the saturation process was dissolved in water, dialyzed free from sulphate and speedily evaporated to dryness at $40^{\circ} \mathrm{C}$. over a water bath. This product when dissolved in water did not give the heat precipitation test. The residue which remained undigested after four hours was again subjected to digestion for 18 hours longer, and the fluid then treated by the process described above.

3. Summary of Results of Procedures A (I-2).-a. Osseoalbumoid prepared from ossein shavings made in 1900 and kept dry, meanwhile, yielded osseoalbumoses on tryptic digestion.

$b$. Ossein shavings themselves were not appreciably affected by tryptic digestion.

c. Osseoalbumoid made from old desiccated ossein shavings, when subjected to peptic digestion for $\mathrm{I} / 2$ hour, yielded a product which gave a sharp heat-precipitation test; that is, a precipitate came down on heating some of the filtered digestive mixture, which precipitate dissolved on further heating and reappeared on cooling. An aqueous solution of the precipitate produced by $\left(\mathrm{NH}_{4}\right)_{2} \mathrm{SO}_{4}$-saturation of this digestive mixture, gave the same heat-precipitation result. This result could be obtained only when the reaction of the heated solution was acid.

$d$. The pepsin used in the digestion was not responsible for this reaction.

$e$. After subjecting osseoalbumoid (the same product as the above) to peptic digestion for $\mathrm{I}, \mathrm{I} / 2$ and 3 hours, respectively, in no case did the filtered digestive mixture, nor a solution of the $\left(\mathrm{NH}_{4}\right)_{2} \mathrm{SO}_{4}$-saturation precipitate from the digestive mixture, give a heat-precipitation test.

f. Osseoalbumoid isolated from fresh ossein shavings, after 
4 hours of peptic digestion, did not yield products giving a heat-precipitation test.

g. From the above it is obvious that, with the exception of the product obtained at the end of $\mathrm{I} / 2$ hour of peptic digestion of osseoalbumoid, none of the products gave a heat precipitation test, thereby differing from elastoses which have properties not unlike the Bence Jones protein in some respects. However, these products as obtained above, after passage through the body, might be so changed that, when excreted in the urine, they would give reactions like those of the Bence Jones protein. On this basis the following experiments were tried.

B. Subcutaneous Injection of Products of the Peptic DigeSTION OF OSSEOALBUMOID. First Experiment.-The dog in this experiment was under observation in the laboratory for two days previous to the injection and during that time his urine gave no precipitate on heating, but saturation with $\left(\mathrm{NH}_{4}\right)_{2} \mathrm{SO}_{4}$ produced a small amount of yellowish precipitate soluble in $\mathrm{H}_{2} \mathrm{O}$. On heating this solution, no precipitate was formed, nor did it give a reaction with picric acid or trichloracetic acid. The solution gave the spectroscopic picture of urobilin. The urine, however, gave a marked precipitate with potassio-mercuric iodid. This precipitate dissolved on further heating and reappeared on cooling. The urine did not give a precipitate with picric acid or trichloracetic acid. ${ }^{1}$

${ }^{1}$ It was thought that the reaction with potassio-mercuric iodid might be due to the fact that the dog had a considerable amount of muco-purulent material in the inner canthus of both eyes and that this material had gotten into the urine. Some of this material from the eyes was obtained, made into a solution with 0.85 per cent. $\mathrm{NaCl}$, filtered, and on adding potassio-mercuric iodide gave a faint precipitate, which did not disappear on further heating, however. As the solution was comparatively concentrated, it was diluted until its content of material was equal to about the maximum proportion that could be present in the urine. At this dilution a marked clouding, but no precipitate, appeared in the test with potassio-mercuric iodide.

The infection of the dog's eyes was removed by irrigations with boric acid, and the cage in which the dog was kept, was thoroughly cleansed. The urine continued to give the reaction with potassio-mercuric iodid, however, after the muco-pus as a factor in its production was ruled out. (See the foot-note on the opposite page.) 
0.3895 gram of the substance obtained by peptic digestion of osseoalbumoid $(A, 2, b)$ was dissolved in $6 \mathrm{cc}$. of 0.85 per cent. $\mathrm{NaCl}$, which were then injected into the loose cellular tissue of the right flank at II.5O A.M., Nov. 27, 1908.

Weight of the dog: 9.65 kilos; temperature of the dog: IOI.20. Amount of substance injected per kilo of dog: 0.040 gram.

The dog showed great lassitude for about seven hours after the injection. ${ }^{1}$

Certain urinary data are given in Table I on page 24 .

The remainder of each fraction of urine after the following tests had been made was saturated with $\left(\mathrm{NH}_{4}\right)_{2} \mathrm{SO}_{4}$ at room temperature and the precipitate collected. Fractions No. 2 and No. 3 gave small amounts of proteose-like precipitates, and fraction No. I a still smaller yield. These precipitates were dissolved in water, filtered and the filtrates tested with the results shown in Table II (page 24).

The filtrates from the precipitates obtained by saturation with $\left(\mathrm{NH}_{4}\right)_{2} \mathrm{SO}_{4}$ at room temperature (Table II) were further saturated with $\left(\mathrm{NH}_{4}\right)_{2} \mathrm{SO}_{4}$ at the boiling temperature. The precipitates were collected, dissolved in water, filtered and tested with the results shown in Table III (page 25).

1 The urine was collected before the injection (after the purulent material from the eyes had been ruled out as a factor in the reaction with potassio-mercuric iodide) and preserved with thymol. As it was subsequently thought that perhaps this preservative might account for the reaction obtained, urine that did not give the test was preserved with thymol, and allowed to stand for twelve hours. It then gave a precipitate with potassio-mercuric iodide, which dissolved on further heating and reappeared on cooling. The same urine gave no precipitate with picric acid or trichloracetic acid, however, This test was repeated several times with the same result.

(The nature of this reaction is being studied and will be the subject of a future communication.) 


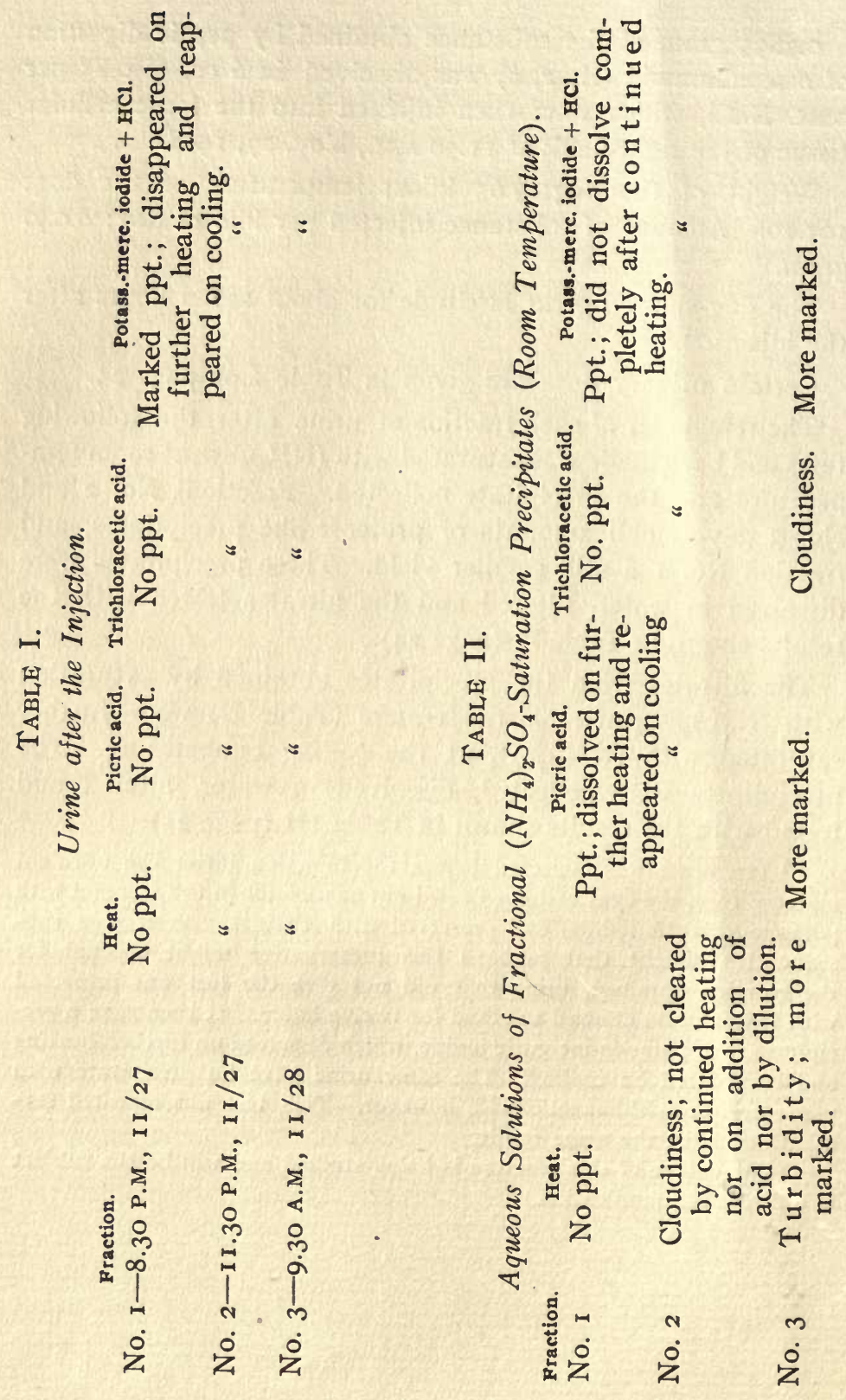


25

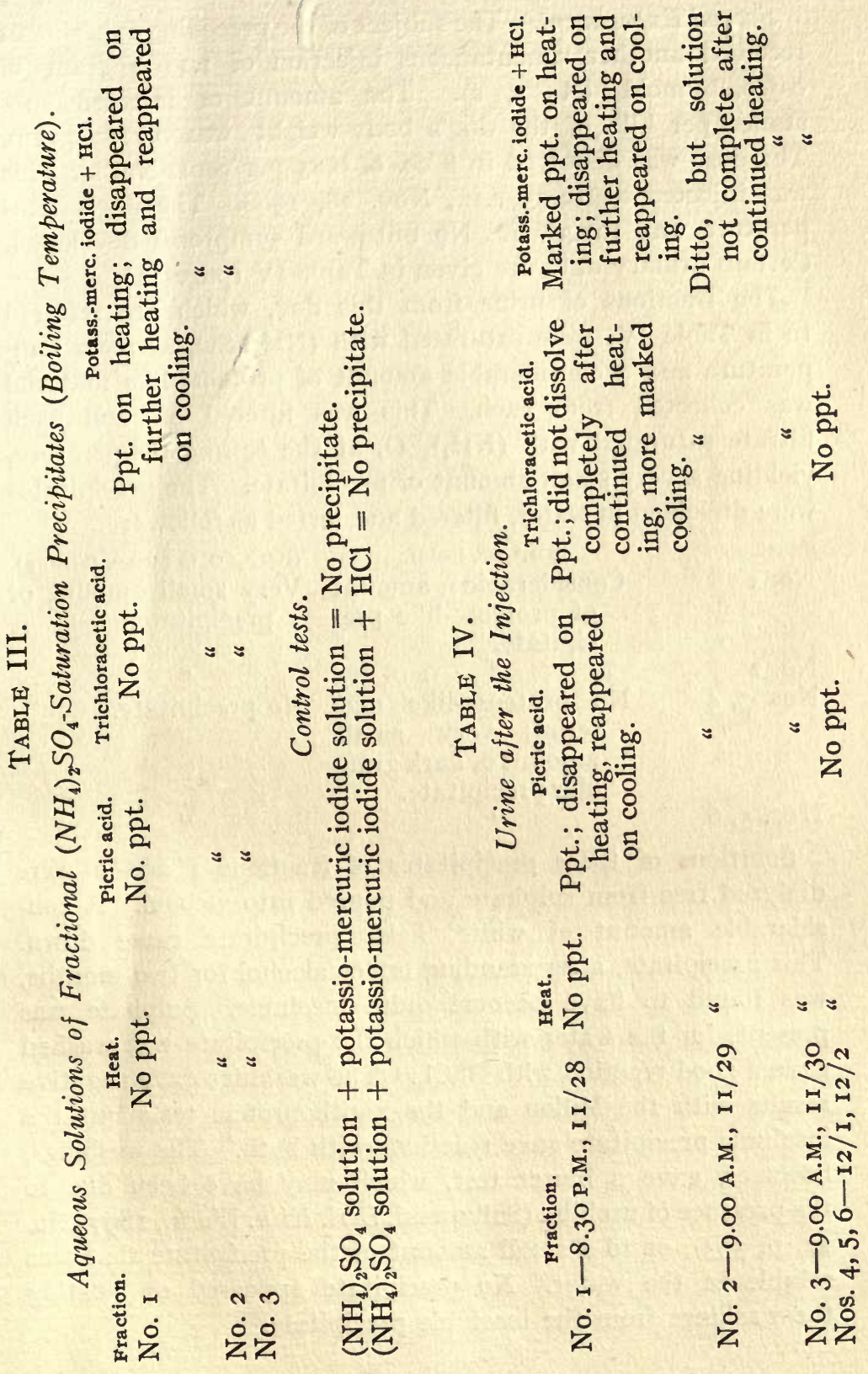


Second Experiment.-The subject of the preceding experiment received another subcutaneous injection of 1.1460 gram of osseoalbumoid $(A, 2, c)$. The amount of injected substance per kilo of the dog's body-weight was 0.1187 gram. The dose was dissolved in $8 \mathrm{cc}$. of 0.85 per cent. $\mathrm{NaCl}$. This was injected at 12.05 P.M., Nov. 28 , 1908. The dog's temperature was ror. $3^{\circ} \mathrm{F}$. No untoward symptoms developed. Certain urinary data are given in Table IV (page 25).

The fractions of urine from this $\mathrm{dog}$, which are referred to in Table IV, were saturated with $\left(\mathrm{NH}_{4}\right)_{2} \mathrm{SO}_{4}$ at room temperature and a considerable amount of proteose-like material was collected from each. This was filtered off and each filtrate saturated with $\left(\mathrm{NH}_{4}\right)_{2} \mathrm{SO}_{4}$ at the boiling temperature, yielding a very small amount of precipitate. The precipitates: were dissolved in water, filtered and tested as follows:

Fraction.

No. I

No. 2

Nos 3,4

Nos. 5,6
$\left(\mathrm{NH}_{4}\right)_{2} \mathrm{SO}_{4}$ (cold).

Considerable amount of proteose-like precipitate.

“

No proteose-like material; very small amount of dark granular precipitate.
$\left(\mathrm{NH}_{4}\right)_{2} \mathrm{SO}_{4}$ to filtrate (boiling).

Very small amount of precipitate.

《6

No precipitate.

“

Solutions of these precipitates of fractions I and 2 were dialyzed free from sulphate and poured into alcohol. A considerable amount of white, flaky precipitate came down. This precipitate, after standing under alcohol for two months, was found to have become quite insoluble. Sulphate was present, for the water with which the precipitate was washed gave a good reaction with $\mathrm{BaCl}_{2}$. The washings gave negative results with the Millon and the xanthoproteic tests but the insoluble precipitate gave reactions with both. The washings, however, gave a biuret test, which may have been due to the presence of urobilin (Salkowski, Berl. Klin. Woch., 1897, No. 17, p. 353), or to a small amount of the precipitate that was soluble in the water. No precipitate appeared on heating the washings from the insoluble precipitate. 


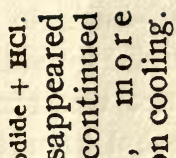

䨔 800

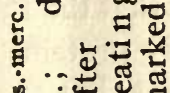

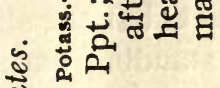

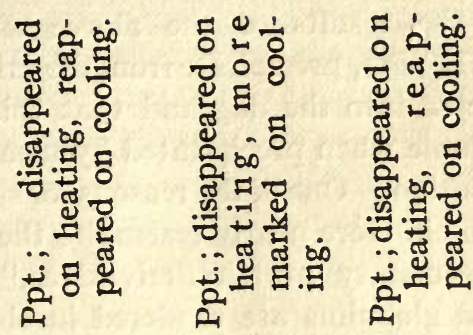

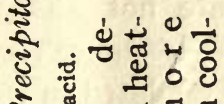

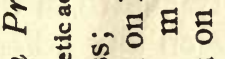

.

월

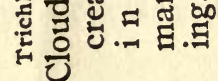

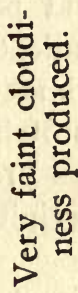

.

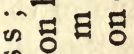

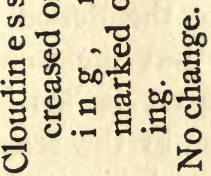

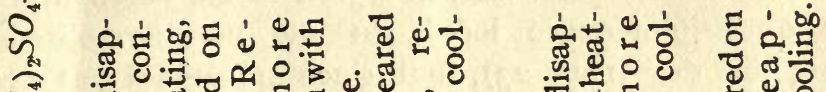

$>$ స

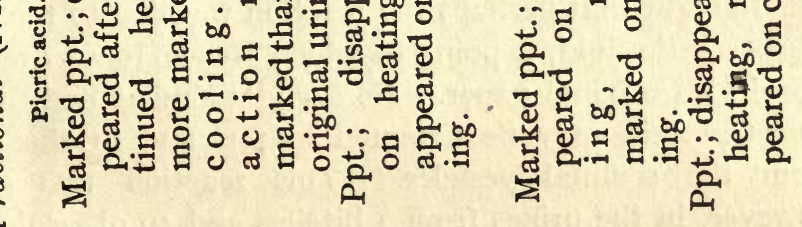

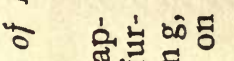

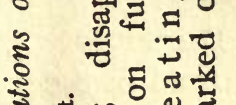

密

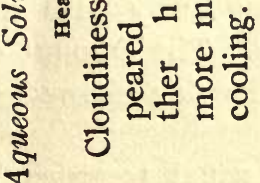

i啇

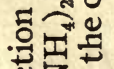

已ृ.

II

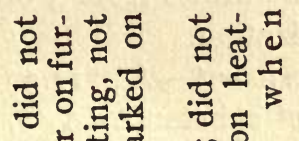

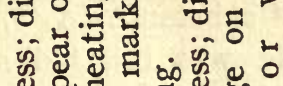

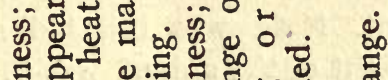

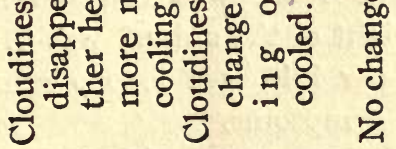

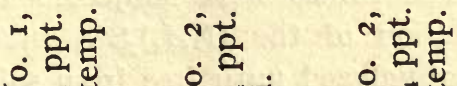

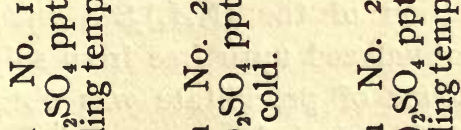

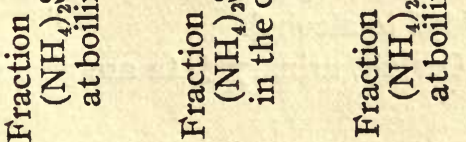


The results of the above experiment indicate that the $\left(\mathrm{NH}_{4}\right)_{2} \mathrm{SO}_{4}$ precipitate from the urine contained the substance injected into the dog and that this substance was rendered insoluble when precipitated by means of alcohol from its aqueous solution. One of the reasons for supposing that the Bence Jones protein more nearly resembles the "primary proteins" than the "secondary protein derivatives," is the fact that the albumins and globulins are rendered insoluble on standing under alcohol while the proteoses and peptones are not. The result referred to above seems to indicate that the substance recovered from the urine in this experiment is closely related in its properties to the Bence Jones protein, for Simon and others have shown that the Bence Jones protein is rendered insoluble in water after it has been precipitated by alcohol and allowed to stand in the reagent.

I may also remark here, in regard to the reaction produced by potassio-mercuric iodide in the non-thymolized urine from this dog (page 23), that, since the animal was a male, it was thought that perhaps the reaction was due to the presence of spermatic fluid, a point to which Bence Jones drew attention in his original paper. He says "a similar body to Bence Jones protein may be detected in pus and in the secretion from the seminal vesicles." This reaction was obtained, however, in the urines from 3 bitches and ro other dogs, even after catheterization.

Third Experiment.-At II.30 A.M., December 24, 1908, 0.7801 gram of substance $(A, 2, d)$ dissolved in $8 \mathrm{cc}$. of 0.85 per cent. $\mathrm{NaCl}$ was injected subcutaneously into a bitch. The weight of the animal was 7.r kilos. The amount of substance per kilo was 0.1099 gram. The dog showed no abnormal symptoms.

The urines were subjected to the usual treatment. The solution of the $\left(\mathrm{NH}_{4}\right)_{2} \mathrm{SO}_{4}$ precipitate from fraction No. I was dialyzed until free from sulphate. At this point a small amount of precipitate was obtained when the solution was added to alcohol.

Certain urinary data are given in Table VI (page 29). 
ปี่

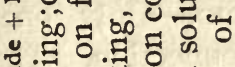

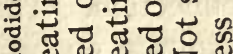

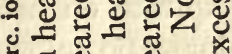

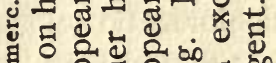

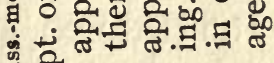

ปึँ

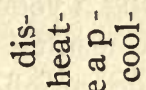

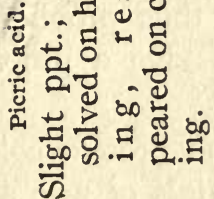

$==\frac{\stackrel{+}{n}}{\frac{0}{2}}$

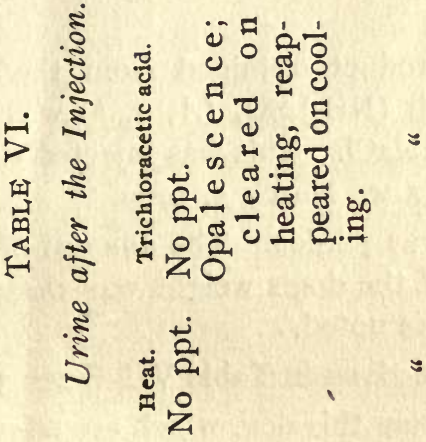

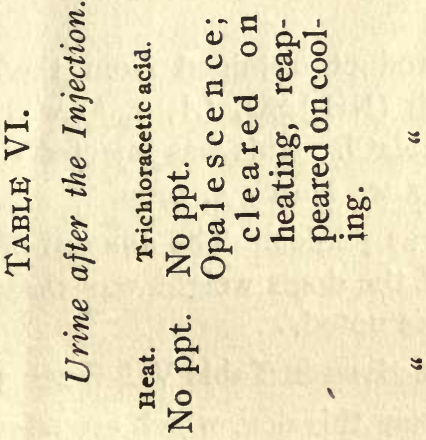

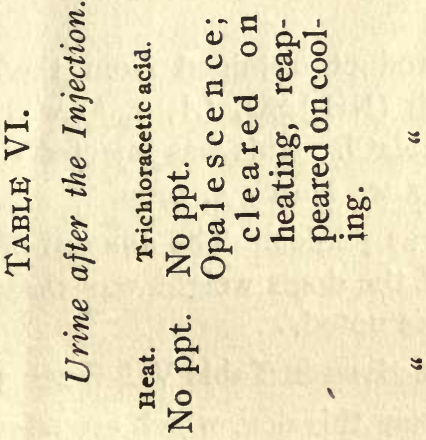

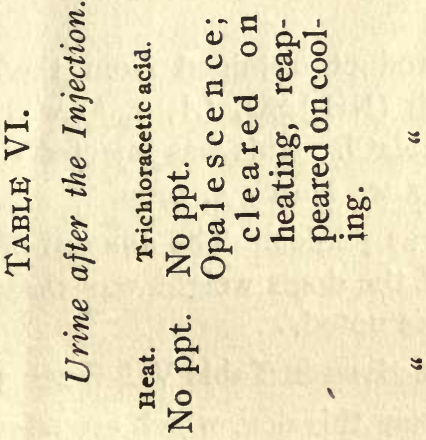

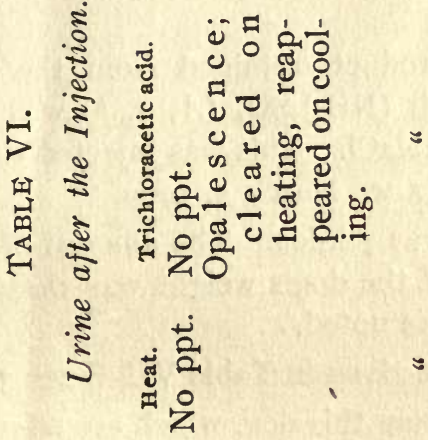

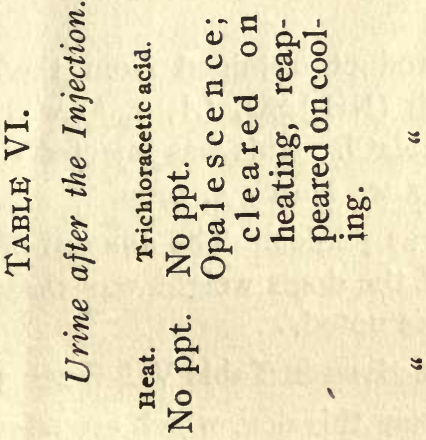

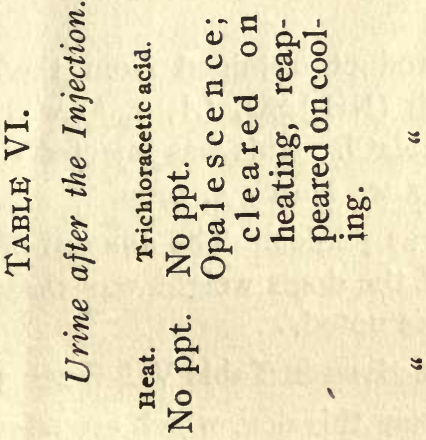

$\Xi$

$\approx \approx=$

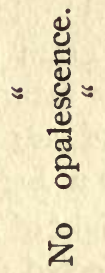

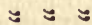

范范

范: =

告

"艹

은

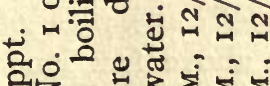

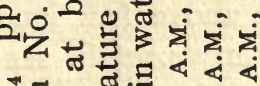

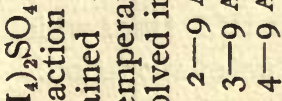

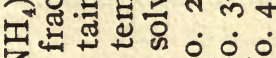

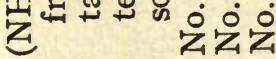


C. Subcutaneous Injection of Products of the Tryptic DigESTION OF OSSEOALBUMOID.-Only one experiment was conducted in this particular connection. The urine of the dog before injection gave no precipitate on heating nor on the addition of picric acid or trichloracetic acid.

The urine was saturated with $\left(\mathrm{NH}_{4}\right)_{2} \mathrm{SO}_{4}$ at the boiling temperature, and a dark granular precipitate obtained, which was slightly soluble in water yielding a yellow colored solution. This yellow solution gave negative results in all the protein color tests except the biuret, thus proving the presence of urobilin; nor did the solution give a protein reaction with picric acid or trichloracetic acid.

The insoluble matter gave no protein color tests and was soluble in acid, depositing crystals of uric acid from an acid solution on evaporation.

0.9145 gram of the product obtained from the digestion filtrate by saturation with $\left(\mathrm{NH}_{4}\right)_{2} \mathrm{SO}_{4}(A, I, b)$ was dissolved in I I cc. of 0.85 per cent. $\mathrm{NaCl}$. This was injected subcutaneously into a dog at 10.45 A.M., March 5, 1909.

The weight of the dog was 7 kilos. The amount of the substance injected per kilo of the dog's weight was 0.1306 gram. No unfavorable effects were noted.

Certain urinary data are given in Table VII (page $3 \mathrm{I}$ ).

The fractions of urine from this dog, which are referred to in Table VII, were saturated with $\left(\mathrm{NH}_{4}\right)_{2} \mathrm{SO}_{4}$ at the boiling temperature. All the fractions, except No. I, yielded a considerable amount of proteose-like precipitate, especially fraction No. 3. The precipitates produced in the fractions were dissolved in water and tested with the results shown in Table VIII (page 32).

The small amounts of $\left(\mathrm{NH}_{4}\right)_{2} \mathrm{SO}_{4}$ precipitates obtained from the above fractions that were insoluble in water did not give any protein reactions, and were almost completely soluble in $\mathrm{HCl}$, from which solutions crystals of uric acid were obtained on evaporation. 
3I

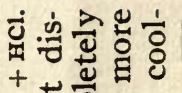

$+5$

o.

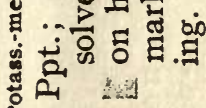

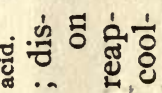

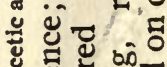

跑

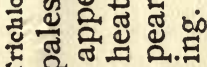

है

赵

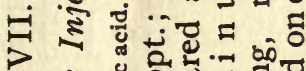

월

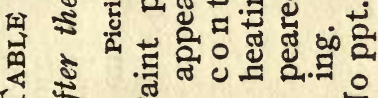

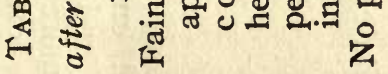

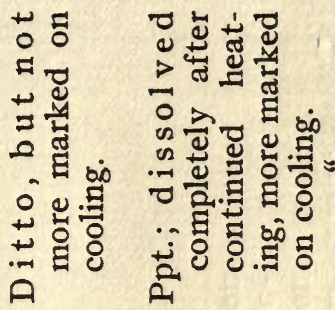

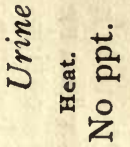

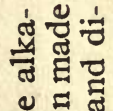

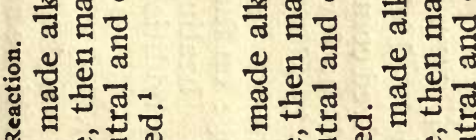

然

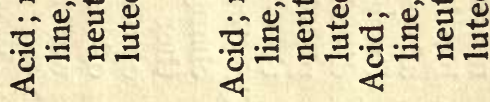

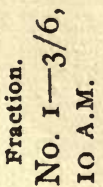

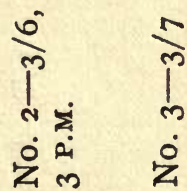

$\prod^{\infty}$

in

字 


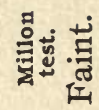

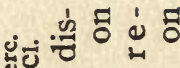

园旸

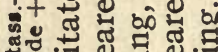

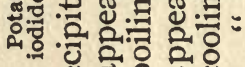

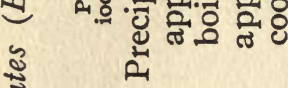

ह

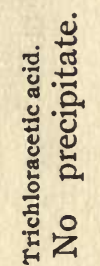

(I)

己

ㅎำ 운

幽

号

¿
密

$\approx$

光 मี

ثี 000

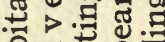

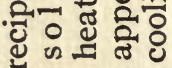

คิ

- म

ț

号

is

य०

$\exists+80^{\circ}$.

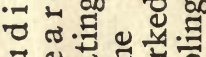

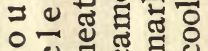

ग

U०

का

마마

ㅇํำ

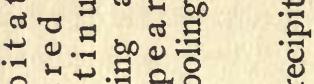

늠

已ัँ

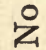

v

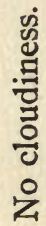

is 혀융명

(1)

두 o b o d o

๑

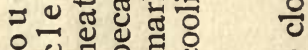

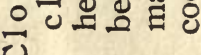

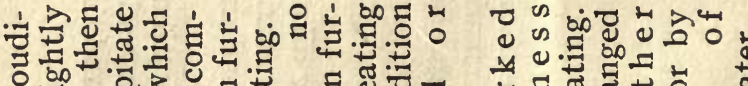

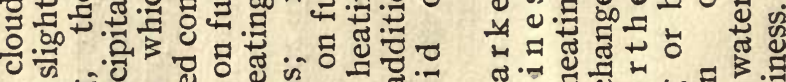
ธี. 岛记

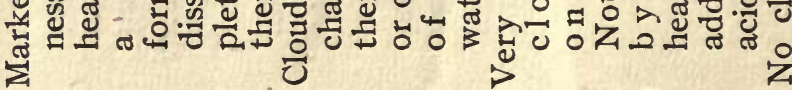


The above data show that the injected material was excreted in the urine in considerable amounts. While it did not yield the heat-precipitation test in the urine, it did give a strong reaction in an aqueous solution of the $\left(\mathrm{NH}_{4}\right)_{2} \mathrm{SO}_{4}$ precipitate from the urine.

Of course it is to be noted that in the case of the plain urine, we have much less of the injected material corresponding to the Bence Jones body than is present in cases of "myelopathic albumosuria," and the fact has been commented upon by Coriat, Hutchison, Rosin, Simon, Sussman, Matthes, Rostoski, Ribbinik, Huppert and Magnus-Levy, that in their cases, although the precipitate was obtained in the urine at low temperature, it did not completely dissolve on further heating. The disappearance of the precipitate after continued heating is not always noted even when the Bence Jones protein is present, as the above-named observers showed, and this reaction is not a true test for the Bence Jones protein. We must bear in mind that the influence of salts has a great deal to do with the solution and precipitation of this protein as is the case with other proteins. This fact has been demonstrated by Spiro, ${ }^{1}$ Pauli and Rona ${ }^{2}$ and Hammarsten. ${ }^{3}$

In order to clear up the obscure points relating to the protein excreted in this experiment, the aqueous solution of the precipitates obtained from the urine by treatment with $\left(\mathrm{NH}_{4}\right)_{2} \mathrm{SO}_{4}$ was dialyzed till free from sulphate and speedily evaporated over a water bath until the liquid had a syrupy consistency. The following experiment was undertaken to find out what reactions occur on heating a sample of urine (sp. gr. 10.20) containing an amount of the substance approximately equal to the proportion in which it exists in cases of myelopathic proteosuria. When the syrupy solution of the excreted substance was added to the urine in varying proportions, no change in the urine took place on heating. The treated urine gave marked precipitates with picric acid and trichloracetic acid, however. These reactions did not take

${ }^{1}$ Spiro: Zt. phys. Ch., I900, xxx, p. 182.

2 Pauli and Rona: Beit. f. ch. Phys. und Path., r902, ii, p. r.

${ }^{3}$ Hammarsten: Pflüger's Arch. f. d. ges. Phys., 1878, xxviii, p. 65. 
place before the addition of the excreted substance. The precipitates dissolved on further heating and became more marked on cooling.

Summary of Results of Procedures B-C.- $\mathrm{r}$. After the subcutaneous injection of products of peptic digestion of osseoalbumoid the urine in no instance gave the heat-precipitation test, but the urine gave the proteose test on addition of picric acid or trichloracetic acid. An aqueous solution of the $\left(\mathrm{NH}_{4}\right)_{2} \mathrm{SO}_{4^{-}}$ saturation precipitate gave the heat-precipitation test and the proteose test with picric acid and trichloracetic acid.

2. The substance excreted in the urine became insoluble after its precipitation with alcohol, thereby resembling the primary proteins rather than the proteoses.

3. Thymolized urines give a reaction with potassio-mercuric iodide that resembles that given by the proteoses with the same reagent.

4. The urine from normal dogs also gave a reaction with potassiomercuric iodide that resembles the proteose reaction with this reagent. The relation between this reaction and the presence of kynurenic acid and "diamines," in dog's urine, is being studied.

5. After the subcutaneous injection of products obtained by tryptic digestion of osseoalbumoid, no heat-precipitation test was obtained in the urine, but the urine gave a good proteose test with picric acid and trichloracetic acid. An aqueous solution of the $\left(\mathrm{NH}_{4}\right)_{2} \mathrm{SO}_{4}$-saturation precipitate gave a marked heat-precipitation test and also proteose tests with picric acid and trichloracetic acid.

6. When some of the substance excreted in the urine was isolated and its aqueous solution concentrated to a syrupy consistency and added to urine of $\mathrm{r} .020$ specific gravity in varying proportions, no heat-precipitation test was obtained. The urine, however, gave marked tests for proteose with picric acid and trichloracetic acid.

7. The injection of these products did not produce any untoward effects.

8. It seems fair to assume, on account of the fact that the heat-precipitation test was not obtained in the urine direct 


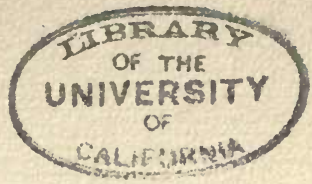

but in an aqueous solution of the $\left(\mathrm{NH}_{4}\right)_{2} \mathrm{SO}_{4}$-saturation precipitate from the urine, that if a larger amount of substance had been present, the heat-precipitation test would have been obtained in the urine itself.

D. LeUCocytic PRoteolysis of OSSEOALBUmoid.-The original assumption which led to this work was that the proteolytic enzymes in the cells of the new bone growth, or the unrestrained action of the enzymes from the bone marrow cells, might cause the production of the Bence Jones protein by the transformation of osseoalbumoid. It was desirable, therefore, to ascertain what the direct action of the enzymes of leucocytes would be on osseoalbumoid and to learn the results that would occur if the substances produced by their proteolysis were injected into dogs.

The method described by Opie (Jr. Exp. Med., 1906, viii, p. 410) was used to obtain the leucocytes and to separate the enzymes from them in a dry, powdered state. By this method Opie has shown that an enzyme designated by him "lymphoprotease" is destroyed when present in an acid medium, and that one which he calls "leucoprotease" remains active when contained in an alkaline medium. The alkaline condition was favorable for our proposed experiment, as the leucoprotease would, in bone marrow, normally act in an alkaline medium. Opie has shown also ( $J r$. Exp. Med., 1905, vii, p. 759) that the enzymes from bone marrow are identical with those obtained from polynuclear leucocytes with fine granulations, and, since these cells are formed in the bone marrow, the bone marrow may be regarded as the source of the enzymes which both contain. Furthermore, Opie has shown that the "lympho-protease" is contained in the lymphocytes, and although the greater proportion of the cells in an inflammatory exudate are polynuclears, there are a number of lymphocytes present, and by his method of preparation, the enzymotic action of the lymphocytes is eliminated.

In the experiment described below a portion of osseoalbumoid was treated with a suspension of 2.35 grams of dry, powdered leucocytes in saline solution. About $800 \mathrm{cc}$. of 0.25 per cent. $\mathrm{Na}_{2} \mathrm{CO}_{3}$ and $\mathrm{I}$ cc. of toluol were added and the 
mixture placed in an incubator at $39^{\circ} \mathrm{C}$. At the end of a week, about one-half of the material was digested. ${ }^{1}$

After twelve days' digestion of the osseoalbumoid by the leucocytic material, it was observed that the amount of undigested matter did not diminish on the two succeeding days. The mixture was then filtered, and the filtrate neutralized and saturated with $\left(\mathrm{NH}_{4}\right)_{2} \mathrm{SO}_{4}$ at the boiling temperature. A very large amount of proteose-like material was obtained. Even after repeated treatment of this precipitate with water a considerable amount of substance remained insoluble. This insoluble portion gave all the protein color reactions, but no proteose tests, and proved to be an alkali albuminate. That portion of the precipitate which was soluble in water was dialyzed free from sulphate and concentrated speedily by evaporation at $40^{\circ} \mathrm{C}$. On heating an aqueous solution of the above precipitate a marked cloudiness was produced, which was not changed on further heating, nor by the addition of acid.

With picric acid, trichloracetic acid, or potassio-mercuric iodide, the solution gave very abundant precipitates which dissolved almost completely on further heating and were more marked on cooling. On addition of concentrated $\mathrm{HNO}_{3}$ a precipitate was produced which dissolved completely on heating and returned on cooling.

The extract of leucocytes did not give a precipitate on heating, nor when allowed to undergo autolysis under toluol. On saturating this autolyzed extract with $\left(\mathrm{NH}_{4}\right)_{2} \mathrm{SO}_{4}$ a small amount of precipitate came down, which, after solution in water, did not respond to the heat-precipitation test.

The osseoalbumoid that was not digested after two weeks' treatment with the dried leucocytic product was transferred to

1 The following references to enzymes from leucocytes may be noted: Longcope and Donhauser: Jr. Exp. Med., 1908, 10, p. 6r8. Opie: Jr. Exp. Med., 1905, 7, pp. 316, 759; 1906, 8, pp. 536, 4 10. Opie and Barker: 1907 , 9, p. 207 . Jochman: Zt. f. Hyg. u. Inf. Krank., I908, 6r, p. 7 I. Jochman and Lockemann: Beiträge. f. ch. Phys. u. Path., 1902, 2, p. 449. Jochmann and Müller: Münch. Med. Woch., 1906, 53, p. I392, 1507, and 2002; also, Verhand. d. Kong. f. inn. Med., Wiesbaden, 1907. 
a fresh saline extract of leucocytes and placed under toluol in an incubator.

After two weeks' digestion in this fresh saline extract of leucocytes there was still some residue present. This was filtered off, the filtrate saturated with $\left(\mathrm{NH}_{4}\right)_{2} \mathrm{SO}_{4}$ at the boiling temperature and an abundant proteose precipitate obtained, which dissolved easily in water forming a dark brown solution. On heating this solution an abundant precipitate came down which dissolved to a slight extent on further heating and which became more marked on cooling. This same result was obtained with picric acid. With trichloracetic acid a precipitate was formed which was not completely soluble on further heating, and which became more marked on cooling. The same results were obtained with potassio-mercuric iodide. With $\mathrm{HNO}_{3}$ an abundant precipitate was produced, which disappeared on heating and returned on cooling. The solution was dialyzed till free from sulphate and evaporated speedily to dryness at $40^{\circ} \mathrm{C}$. As it was thought that the undigested material might be collagen, it was boiled with water but the supernatant liquid gave only a slight reaction for protein.

To determine if this residue was digestible it was treated with a fresh active alkaline trypsin mixture and placed in an incubator. After 48 hours no digestion had taken place, and on saturation with $\left(\mathrm{NH}_{4}\right)_{2} \mathrm{SO}_{4}$, no precipitate came down. Most of the undigested material dissolved in $\mathrm{Na}_{2} \mathrm{CO}_{3}$ from which it could be precipitated by acidifying the alkaline solution with $\mathrm{HCl}$. This material consisted chiefly of hematin as seemed evident also from its color.

Summary of Results of Procedure D.-r. Osseoalbumoid, on digestion with a dried extract of leucocytes, prepared by the method of Opie, yielded osseoalbumoses.

2. An aqueous solution of the osseoalbumoses produced by the leucocytic proteolysis of osseoalbumoid did not give a sharp heat-precipitation test. However, after the addition of picric acid, trichloracetic acid, nitric acid, or potassiomercuric iodide, a sharp proteose test was obtained.

3. Neither the extract of leucocytes nor the autolyzed leucocytic material gave a heat-precipitation test. 
E. Subcutaneous Injection of Products ObTaIned in THE LEUCOCYTIC PROTEOLYSIS OF OSSEOALBUMOID.-2.3060 grams of the proteose-like product (D) were dissolved in I I cc. of 0.85 per cent. $\mathrm{NaCl}$. This solution was injected subcutaneously into a bitch, the subject of a former experiment. The weight of the dog was 7 kilos. The amount of the substance injected per kilo of dog's weight was 0.33 gram. Injection occurred at II A.M., March I6, '09. No untoward effects were noticed.

Certain urinary data are given in Table IX (page 39).

The several fractions of urine from this dog, which are referred to in Table IX, were saturated with $\left(\mathrm{NH}_{4}\right)_{2} \mathrm{SO}_{4}$ at the boiling temperature. Fractions 2, 4 and 5 gave fair amounts of precipitates. These precipitates were found to be very slightly, if at all, soluble in water. They were insoluble in $\mathrm{NaCl}, 0.2 \%$ $\mathrm{HCl}$ and $\mathrm{C}_{2} \mathrm{H}_{5} \mathrm{OH}$, but soluble in $0.5 \% \mathrm{Na}_{2} \mathrm{CO}_{3}$. The insoluble material gave very marked responses to the Millon and xanthoproteic tests. The filtrate from the material insoluble in water gave no reactions with picric acid, Millon's reagent or potassio-mercuric iodide.

It was thought that this excreted substance might be nucleoalbumin. Some of the original urine was therefore rendered amphoteric to litmus, heated to boiling and, while briskly boiling, treated with acetic acid drop by drop. A white, flaky precipitate was produced, which was filtered off, and which gave the following reactions:

(I) Soluble in excess of 0.2 per cent. $\mathrm{HCl}$.

(2) On being boiled with 2 per cent. $\mathrm{HCl}$ until a dark color formed, neutralized and tested for reduction with Fehling solution, no reduction was obtained.

(3) Gave positive test for phosphates on evaporation, fusion with $\mathrm{Na}_{2} \mathrm{CO}_{3}$ and $\mathrm{NaNO}_{3}$, and treatment with dilute $\mathrm{HNO}_{3}$ and ammonium molybdate solution. The original precipitate was washed till the washings gave no test for phosphates before the fusion was made.

These results show that the substance excreted was probably nucleoalbumin. No substance giving these reactions of nucleoalbumin was obtained from the urine before the in- 


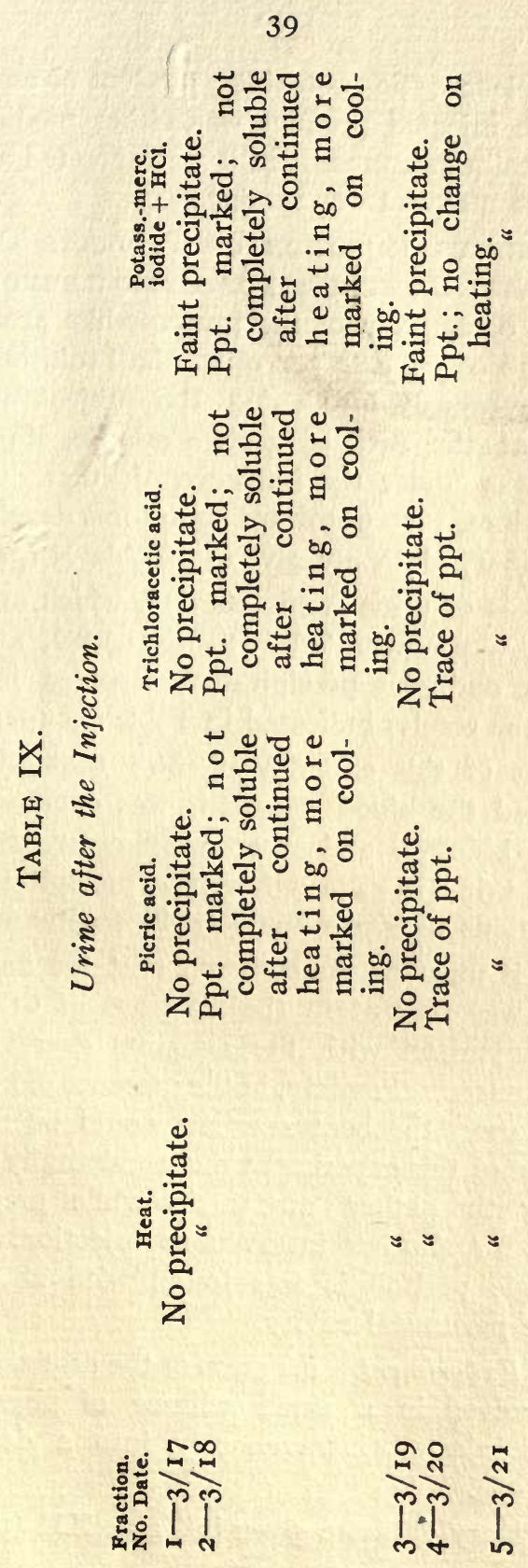


jection of the leucocytic proteolytic product of osseoalbumoid. Evidently the injected product was either modified in some way or nucleoalbumin present in it was excreted as such while the rest of the material was retained.

F. Intravenous InJection of Products Obtained in THE LEUCOCyTIC Proteolysis of OSSEOALBUMoId.- - . First Experiment. 0.865 gram of the proteose-like product (D) was dissolved in $30 \mathrm{cc}$. of 0.85 per cent. $\mathrm{NaCl}$ solution. This was injected intravenously into a dog, the subject of a previous experiment, at the rate of I cc. a minute, March 23, I909. The animal was under the influence of ether during the injection procedure. No untoward symptoms developed.

Certain urinary data are given in Table X (page $4 \mathrm{r}$ ).

The fractions of urine from this dog, which are referred to in Table $\mathrm{X}$, were saturated with $\left(\mathrm{NH}_{4}\right)_{2} \mathrm{SO}_{4}$ at the boiling temperatures and the precipitates dissolved in water and tested with the results indicated in Table XI (page 42).

The results of this experiment show that when the substance reached the blood stream it was excreted unchanged through the kidneys, and when present in sufficient quantities in the urine it gave a fair heat-precipitation test and marked reactions with picric and trichloracetic acids.

Of course it must be remembered that the amount of substance that was present in the fractions of urine was quite small in comparison with the amounts excreted in myelopathic proteosuria. Possibly, in the presence of larger amounts of the substance, the heat reaction would be more marked.

The subject of this experiment was accidentally killed a week later during the ether anesthesia while preparation was being made for another intravenous injection. At autopsy a hemorrhagic peritonitis was found with about $50 \mathrm{cc}$. of blood in the peritoneal cavity.

2. Second Experiment. 0.4 gram of the proteose-like product (D) was dissolved in a small volume of physiological salt solution and injected intravenously into a dog at 2 P.M., March 30, I909.

Certain urinary data are given in Table XII (page 43). 


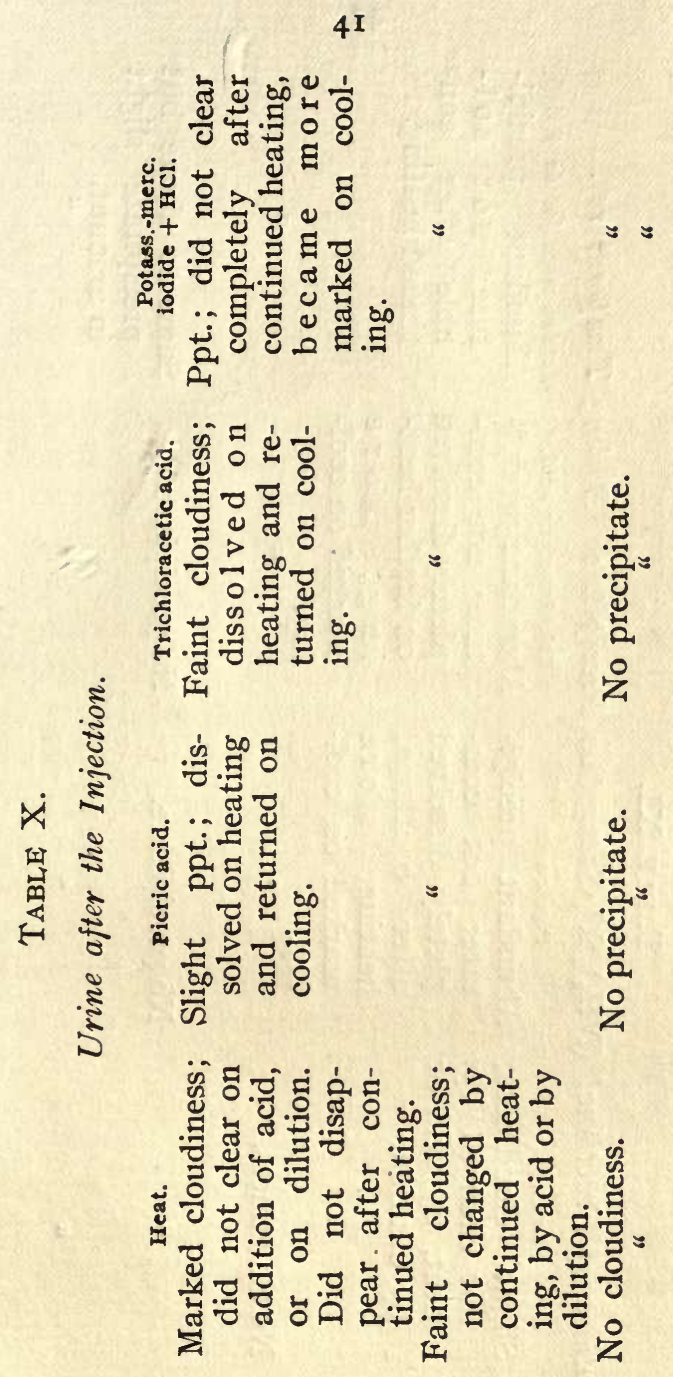

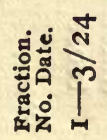

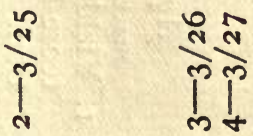




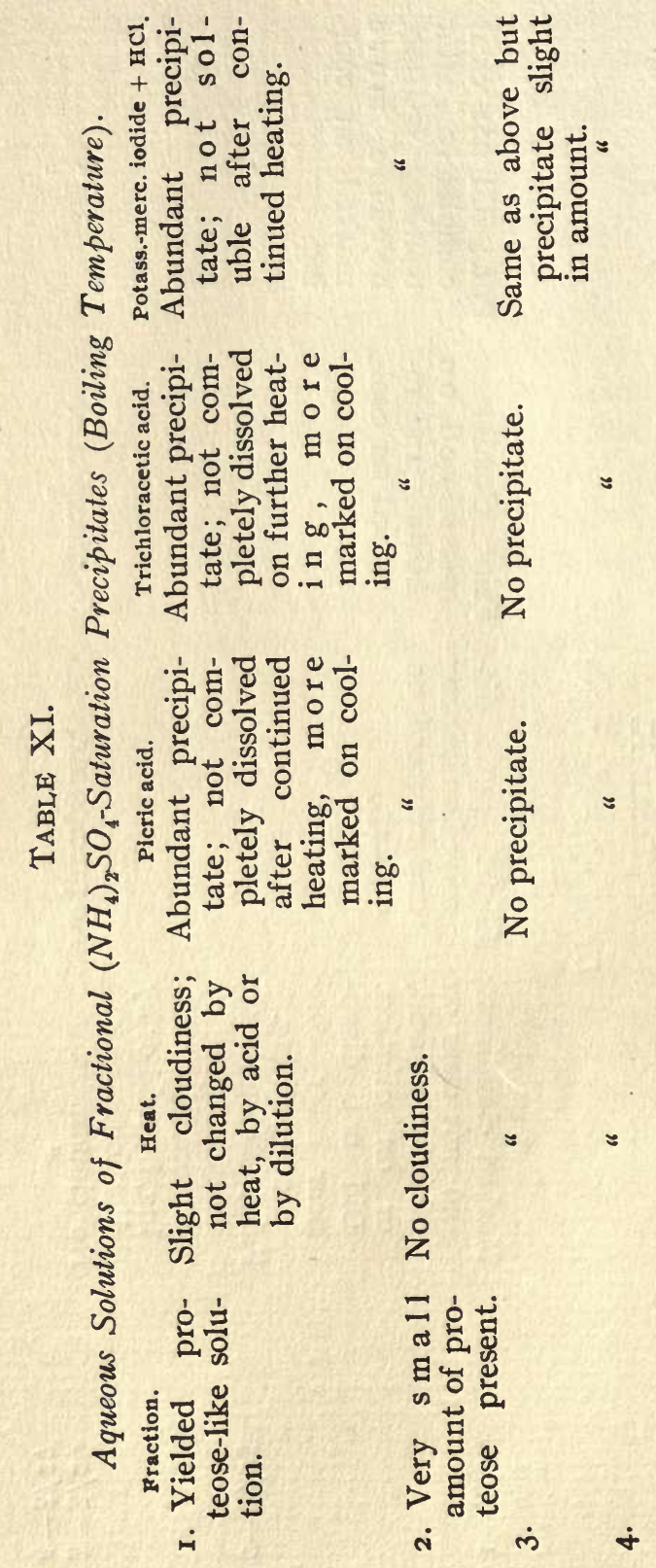



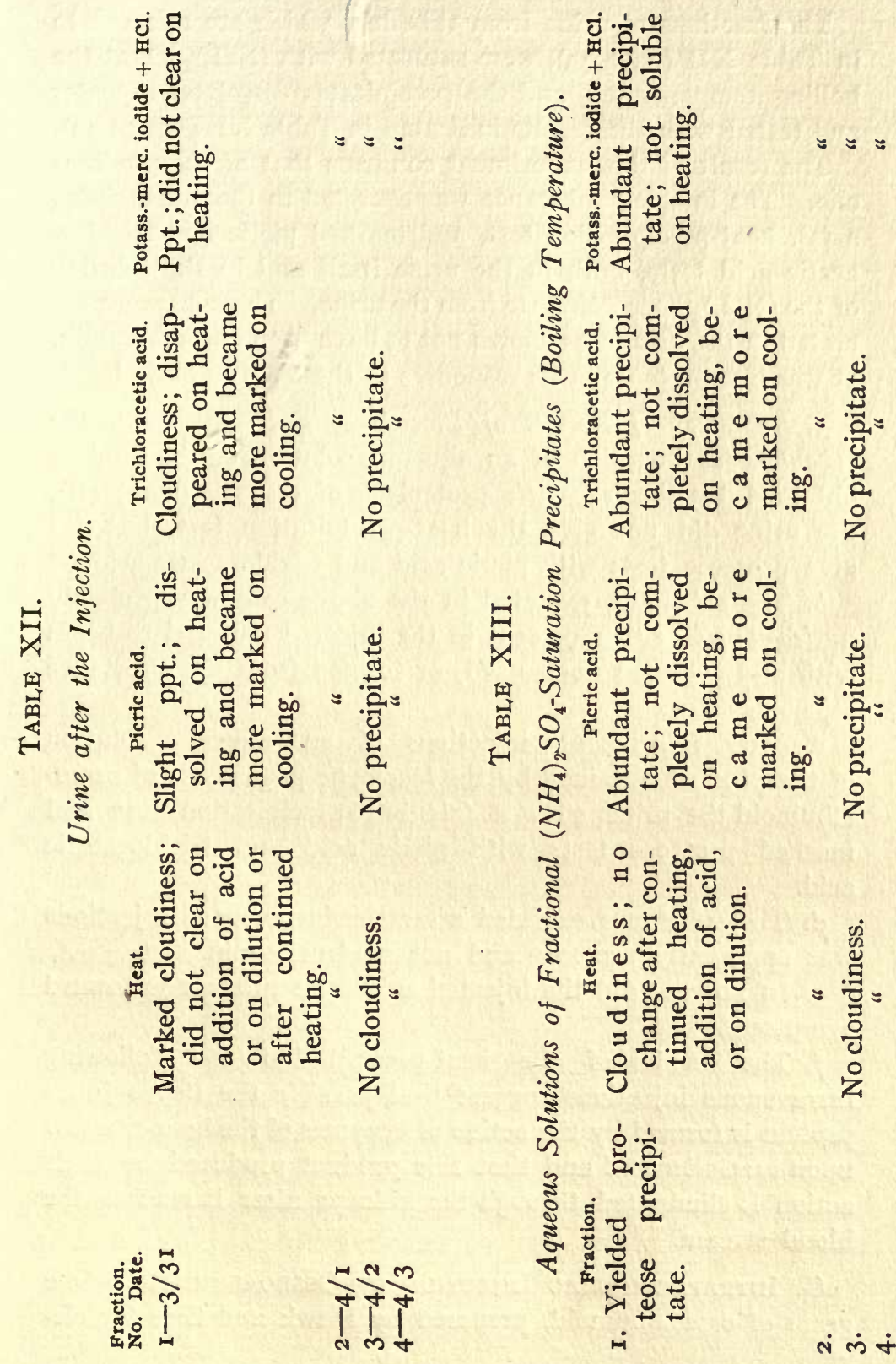

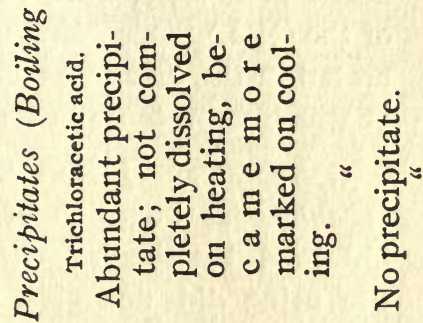
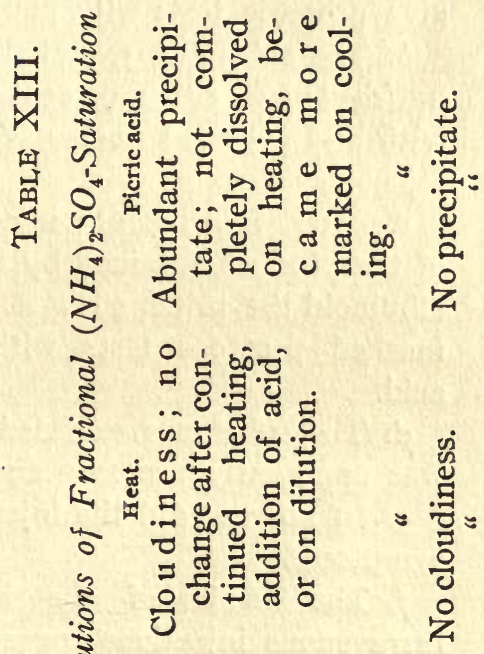
The fractions of urine from this dog, which are referred to in Table XII (page 43), were saturated with $\left(\mathrm{NH}_{4}\right)_{2} \mathrm{SO}_{4}$ at the boiling temperatures, and the precipitates dissolved in water and tested with the results indicated in Table XIII (page 43).

The result of this experiment confirms that of the previous one. The injected substance was excreted in the urine, giving a fair heat-precipitation test, and marked picric and trichloracetic acid tests, both in the urine itself and in the solution of the $\left(\mathrm{NH}_{4}\right)_{2} \mathrm{SO}_{4}$ precipitate from the urine. The substance excreted in the urine was shown not to have been nucleoalbumin. It was like proteose in its responses to the tests employed.

3. Summary of Results of Procedures E-F.-a. After the subcutaneous injection of an aqueous solution of the product obtained by the leucocytic proteolysis of osseoalbumoid (D), the urine did not give the heat-precipitation test, but did give proteose tests with picric acid and trichloracetic acid.

$b$. The substance excreted in the above case was probably nucleoalbumin either present in the injected material to begin with and excreted unchanged, or formed from the substance injected.

c. After intravenous injections of an aqueous solution of the product obtained by the leucocytic proteolysis of osseoalbumoid the urine gave a fair heat-precipitation test and marked proteose tests with picric acid and trichloracetic acid.

$d$. The substance excreted after the intravenous injections was apparently proteose and not nucleoalbumin.

$e$. In no case did the injected substance produce untoward symptoms.

$f$. The results of the heat-precipitation test following intravenous injections suggest that possibly the Bence Jones protein is formed by the action of enzymes of the bone-marrow upon osseoalbumoid and that this product produced by their action is eliminated through the kidneys after it reaches the blood stream.

G. INTRAPERITONEAL INJECTION OF OSSEOALBUMOID.-One gram of osseoalbumoid, prepared by Hawk and Gies for ele- 
mentary analysis, was suspended in water. The mixture was heated to boiling, cooled and injected intraperitoneally into a large dog at 3 P.M., March 25, 1909.

Certain urinary data are given in Table XIV (page 46).

It was found that the substance excreted consisted of serum proteins. No proteose-like material could be detected.

The urine before injection gave no reaction with picric acid or trichloracetic acid. With potassio-mercuric iodide a slight precipitate was obtained that did not change on further heating. On saturation with $\left(\mathrm{NH}_{4}\right)_{2} \mathrm{SO}_{4}$ a small amount of a dark granular precipitate was obtained that consisted of urates, urobilin, and a small amount of an insoluble residue which gave no reaction for protein.

On March 30 th, the dog died and, on autopsy, a very intense hemorrhagic peritonitis was found with over a liter of bloody fluid in the peritoneum. No proteose could be detected in this fluid. It was hoped that in the experiment just described, the osseoalbumoid would cause an inflammatory reaction and then undergo a proteolysis occasioned by the enzymes of the leucocytes in the exudate and that the product of this digestive action would be taken up by the blood and undergo excretion. Such conditions would bring about a more natural leucocytic . proteolysis of osseoalbumoid and would effect a process more nearly comparable to that supposedly taking place in multiple myeloma. On account of the danger of the intraperitoneal injection, it was decided to attempt to induce more favorable conditions by making an intrapleural injection of osseoalbumoid as described below.

H. INTRAPLEURAL INJECTION OF OSSEOALBUMOID. -0.4 gram of osseoalbumoid (from the same product as that used for the intraperitoneal injection-G) was suspended in ro cc. of physiological salt solution, heated to boiling, cooled, and injected into the left pleural cavity of a dog, at 4 P.M., April 3, 1909 .

The urinary tests were negative (Table XV (page 46)).

All the fractions of urine from this dog (Table XV) were saturated with $\left(\mathrm{NH}_{4}\right)_{2} \mathrm{SO}_{4}$ but fraction 4 (April 7) - was the only one that gave a proteose-like precipitate. A solution 

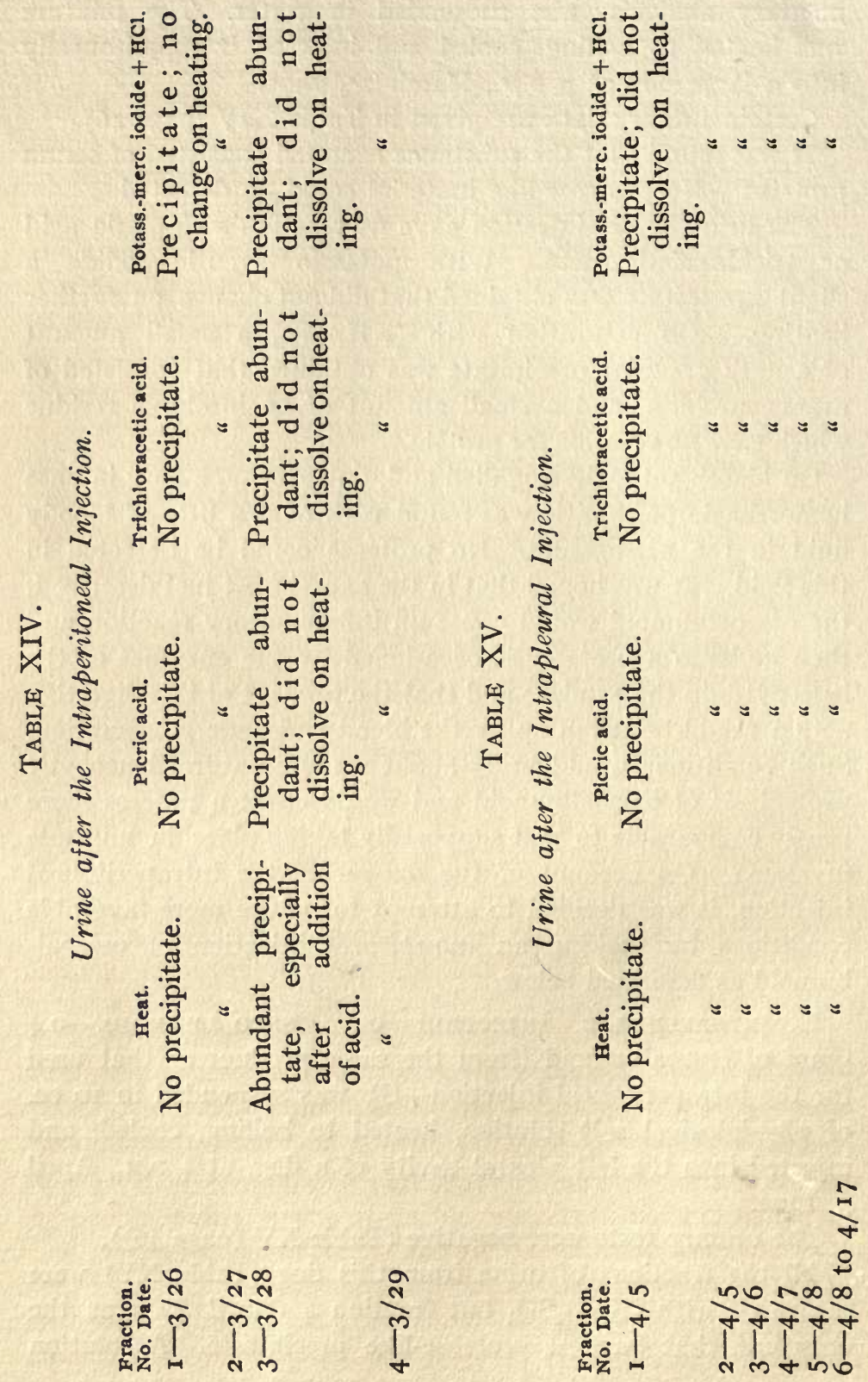
of this precipitate gave a positive reaction for proteose when tested with potassio-mercuric iodide, picric acid and trichloracetic acid. On heating an aqueous solution of the precipitate produced by $\left(\mathrm{NH}_{4}\right)_{2} \mathrm{SO}_{4}$, a marked turbidity ensued that did not disappear completely after continued heating, and was more marked on cooling.

On April I 7 th, two weeks after the intrapleural injection the dog was killed. At autopsy the left lung and pleura were found to be normal, with no evidence of any osseoalbumoid present.

The results of the tests on the urine in this experiment indicate that the injected osseoalbumoid was taken up by the blood and the substance excreted. In one fraction of the urine, obtained four days after the injection, a substance was present which was precipitated by picric acid, the product thus thrown down dissolving on warming and reappearing on cooling-apparently proteose.

Summary of Results of Procedures G-H.-I. Intraperitoneal injection of osseoalbumoid, as a method for the production of the autolytic derivatives of osseoalbumoid in the exudate resulting from its injection, is apparently too unsatisfactory a process for use in such experiments.

2. The urine four days after the intrapleural injection of osseoalbumoid yielded an $\left(\mathrm{NH}_{4}\right)_{2} \mathrm{SO}_{4}$-saturation precipitate whose aqueous solution gave a pronounced heat-precipitation test and marked proteose reactions with picric acid and trichloracetic acid.

\section{SUMMARY OF GENERAL, CONCLUSIONS.}

I. The peptic digestion of osseoalbumoid yielded a watersoluble substance precipitable by saturation with $\left(\mathrm{NH}_{4}\right)_{2} \mathrm{SO}_{4}$. In one instance this material gave a heat-precipitation test, but the reaction was not as marked in its sharpness as the same test when applied to elastose. Negative results were obtained when the test was applied to two other similar products obtained in the peptic digestion of osseoalbumoid.

2. After the subcutaneous injection of the material produced by the peptic digestion of osseoalbumoid, the urine did not 
yield a heat-precipitation test, but gave a positive reaction with picric and trichloracetic acids. The $\left(\mathrm{NH}_{4}\right)_{2} \mathrm{SO}_{4}$ precipitate from the urine in this experiment gave positive heat as well as picric acid and trichloracetic acid tests.

3. The heat-precipitation test in the urine is determined by the amount of substance excreted as well as by the reaction of the urine and the quantity of salts present.

4. After the subcutaneous injection of the material produced by the peptic digestion of osseoalbumoid, an alcoholic precipitate of the substance excreted in the urine is rendered insoluble on standing under alcohol, thereby showing one of the characteristics of the Bence Jones protein, and departing from the usual properties of proteoses.

5. After the subcutaneous injection of the substance obtained by the tryptic digestion of osseoalbumoid, it was excreted by the urine but it did not give a heat precipitation test.

6. Osseoalbumoid undergoes proteolysis when subjected to the action of the enzyme of leucocytes that acts in an alkaline media. A solution of the $\left(\mathrm{NH}_{4}\right)_{2} \mathrm{SO}_{4}$ precipitate of this digestive mixture gave a heat precipitation test as well as reactions with picric acid and trichloracetic acid.

7. The material produced by the leucocytic proteolysis of osseoalbumoid, after its subcutaneous injection, was found to have been modified in the body and was excreted, in whole or in part, as a nucleoalbumin-like substance in the urine.

8. Intraperitoneal injection could not be used as a satisfactory method of favoring autolysis of osseoalbumoid on account of the peritonitis produced.

9. Osseoalbumoid was absorbed, after its intrapleural injection, and a digestive product of it was excreted in the urine. This product in the urine did not give a heat-precipitation test, but a solution of the $\left(\mathrm{NH}_{4}\right)_{2} \mathrm{SO}_{4}$ precipitate from the urine gave this reaction as well as one with picric acid and trichloracetic acid.

Io. Some of the results indicate that the Bence Jones protein may be formed from osseoalbumoid by the action of enzymes present in the bone marrow. 


\section{BIBLIOGRAPHY.}

All references except those marked with * have been verified.

I. Abderhalden (Hall), Physiological Chemistry, r908, p. 269.

2. Abderhalden and Rostoski, Beitrag zur Kenntniss des Bence Jonesschen Eiweisskörpers, Z. f. phys. Chem., r905, xlvi, p. I25.

3. Abrikossoff, Ueber einen Fall von multiplen Myelom mit diffuser Verbreitung im Knochenmark, Virch. Arch., 1903, clxxiii, p. 335.

4. von Aldor, Ueber den Nachweis der Albumosen im Harn und über die Enterogene Albumosurie, Berl. klin. Woch., 1899, xxxvi, pp. 764 and 785 .

5. Allard and Weber, Ueber die Beziehungen der Bence Jonesschen Albumosurie, Deut. med. Woch., 1906, xxxii, p. $125 \mathrm{I}$.

6. Anders and Boston, Bence Jones albumosuria with report of three cases (Bibliography), Lancet, 1903, i, p. 93.

7. Anders and Boston. Above title and review of the literature, Trans. of the Coll. of Phys. (3rd s.), 1902, xxiv, p. 175.

8. Aschoff, Ein Fall von Myelom, Muench. med. Woch., 1906, liii, p. 337 .

9. Askanazy, Ueber die diagnostische Bedeutung der Ausscheidung des Bence Jonesschen Körpers durch den Harn, Deut. Arch. f. klin. Med., 1900, lxviii, p. 34 .

ro. Austin, Products of prolonged bacterial action upon proteins, Jr. of Med. Research, 1903 , ix, (n. s.), iv, p. I.

Ir. Bang, Eine neue Methode zum Nachweiss der Albumosen im Harn, Deut. med. Woch., 1898, xxiv, p. 17.

12. Baumgarten, Myelogene Pseudoleukämie mit Ausganz in allgemeine osteosklerose, Arb. auf d. Geb. der Path. Anat. u Bact aus Tubingen, Baumgarten, 1894-99, ii, p. 449.

*13. Bechtold, Über des multiple Myelom, Dissertation, Wurzburg, 1902.

14. Bell and Keenan, A case of multiple myeloma, Montreal Med. Jr., I902, 1xxxi, p. 336.

15. Benda, Fall von multiplem myelom, Verein f. Inn. Med., Dec. 2, 1908; Abstr. Fol. hematol., 1909, vii, p. 149.

16. Bender, Ueber ein periostales Rundzellensarkom und ein Myelom mit Kalkmetastasen (Literature), Deut. Zeit. f. Chir., 1902, 1xiii, p. 370.

I7. Bertoye, Contribution a l'étude de la Maladie de Bence Jones, Rev. de Med., 1904, xxiv, pp. 257, 390 and 528.

I8. Bignami, Sulla lur fornatosi sistematica midollare ed osteoperiostale, Annali di Med. Navale, r898, iv, p. 5 .

19. Blair, A case of albumosuria, Brit. Med. Jr., 1901, ii, p. 713.

20. Borst, Die Lehre von den Geschwulsten, I902, i, p. 492. 
21. Boston, Clinical Diagnosis, 2nd edit., 1905, p. 218.

22. Boston, Bence Jones albumosuria with peculiar nervous phenomena, Am. Jr. Med. Sci., I903, cxxv, p. 658.

23. Boston, A rapid reaction for Bence Jones albumose, Am. Jr. Med. Sci., 1902, cxxiv, p. 567.

$*_{24}$. Botkin, Dissertation, St. Petersburg, 1893.

25. Bouchstab and Schaposchrikoff, Sur em cas de myelomatose disseminee des os du trouc avec. Albumosurie, Russ. Arch. de Path. de Med. Clin. et de Bact., 1899, vii, p. 86; Abstract, Central. f. allg. Path., I899, X, p. 589 .

26. Bozollo, Sulla malattia di Kahler, La Reformi med., I897, iv, p. 355 ; La Clinica Med. Italiana, 1898, xxxvii, p. I.

27. Bradshaw, A case of albumosuria in which the albumose was spontaneously precipitated, Trans. Med.-Chir. London, 1898, 1xxxi, p. 259; Brit. Med. Jr., I898, i, p. I 136.

28. Bradshaw, The recognition of myelopathic albumose in the urine, Brit. Med. Jr., 1906, ii, p. 1442.

29. Bradshaw, Myelopathic albumosuria, Brit. Med. Jr., 1900, ii, p. 1304; Lancet, 1902, ii, p. 929.

3o. Bradshaw, On the evolution of myelopathic albumosuria, Brit. Med. Jr., I9or, ii, p. 75 .

3r. Bradshaw, Myelopathische albumosurie, Muench. med. Woch., 1902, xlix, p. I91.

32. Bradshaw and Warrington, The morbid anatomy and pathology of Dr. Bradshaw's case of myelopathic albumosuria, London Med. Chir. Trans., 1899, 1xxxii, p. 25I; Proc. Royal Med. and Surg. Soc. of London (3rd s.), 1898-99, xi, p. 8o.

33. Bramwell and Paton, On a crystalline globulin occurring in human urine, Laboratory Reports Royal College of Phys. of Edinburgh, I892, iv, p. 47.

34. Brown, A case of myelopathic albumosuria, Brit. Med. Jr., 1907, ii, p. 626.

35. Bruce, Lund and Whitcomb, Note on a case of myelopathic albumosuria, Lancet, 1904, i, p. 1045.

36. de Buck, La Valeur Alimentaire des Albumoses, La Belgique Medicale, $1896, \mathrm{i}, \mathrm{p} .129$.

37. de Buck, Ueber den Nährwerth der Albumose, Wien. med. Presse, 1896, xxxvii, p. 212.

38. Burr, Albumosuria, Boston Med. and Surg. Jr., 1903, cxlviii, p. 462.

39. Butlin, Myeloid sarcomata of lower jaw and rib; Mollities ossium, Trans. Path. Soc. of London, 1880, xxxi, p. 277.

40. Cale, Bence Jones albumosuria accompanying myeloid sarcoma of the humerus, coincident with trauma, Interstate Med. Jr., St. Louis, 1909, xvi, p. 395. 
41. Católa, A proposito dell álbumosuria di Bence Jones, Riv. crit. di. clin. Med., 1906, vii, p. 175.

42. Charles and Sanguinetti, Multiple myeloma, Brit. Med. Jr., I907, i, p. 196.

43. Chittenden, Digestive proteolysis, N.Y.Med. Record, 1894, xlv, pp. 4I $7,449,481,5$ I $3,545,577$.

44. Chittenden and Bolton, Egg albumin and albumoses, Studies from Lab. of Physiological Chem. Sheff. Scientific School, 1885-88, ii, p. 126.

45. Chittenden and Hart, Elastin and elastoses, Z. f. Biol., 1889, (n. f.), vii, p. 368 .

46. Chittenden and Mendel, On the proteolysis of crystallized globulin, Jr. of Physiol., r894-95, xvii, p. 48.

47. Chittenden, Mendel and Henderson, A chemico-physiological study of certain derivatives of the proteids, Am. Jr. Phys., 1898-99, ii, p. 142 .

48. Christian, Multiple myeloma-a histological comparison of six cases, Trans. Assn. of Amer. Phys., 1907, xxii, p. 145; Jr. of Exp. Med., I907, ix, p. 325.

49. Coats, A case of multiple sarcoma of bone, Glascow Med. Jr., I89I, xxxvi (n. s.), p. 420.

50. Cohnheim, Chemie der Eizweisskörper, 1904, p. 172.

51. Collins, Multiple myeloma (Kahler's disease). A contribution to its symptomatology and morbid anatomy, N.Y. Med. Record, I905, $1 \mathrm{xvii}$, p. $64 \mathrm{I}$.

52. Conti, Albumosuria e Neoplosie sistematiche della ossa (Con un caso clinico), La Clinica Med. Ital., r902, xli, p. 2 I I.

53. Coriat, The occurrence of the Bence Jones albumin in a pleuritic effusion, Am. Jr. Med. Sci., 1903, cxxvi, p. 631.

54. D'Allocco, Sulla Malattia Di Kahler (Mielomi multiple con albumosuria), Arch. Ital. di. Med. Int., 1900, iii, p. 82.

55. Dalrymple, On the microscopic character of Mollities Ossium, Dublin Quart. Jr., 1846, ii, p. 85.

56. Decastello, Beitrag zur Kenntnis der Bence Jonesschen Albuminurie, Z. f. klin. Med., I909, 1xvii, p. 319; Verhand Kongr. inn. Med., I908, xxv, p. 620 (Literature and good review of cases); Abstract Folia hematol., I909, viii, p. 49.

*57. Deiters, Dissertation, Berlin, 1892, L. Schumacher.

58. Dévé, Sarcomatose multiple des os (myelomes multiples), La Normandie Medicale, 1907, xxii, p. 289; Rev. medicale de Normandie, 1907, viii, p. 207.

59. Devic and Beriel, A propos D'un cas de Tumeurs multiples des os sans albumosurie, Rev. de Chir., I906, xxxiv, p. 459.

6o. Dick, A case of multiple myeloma, Trans. Chicago Path. Soc., I903-6, vi, p. 168.

6r. Dickinson and Fyffe, Albumosuria-some cases of, Trans. Clin. Soc. of London, 1892, xxv, p. 64; Abstr. Brit. Med. Jr., 1891, ii, p. 1206. 
*62. Dietschy, Dissertation, Basel, 1906, E. Borkheiser, "Die Albumosurie in Fieber."

63. Donetti, Sulla malattia di Kahler, Rivista crit. di clin. med., I90I, ii, p. 789 .

64. Ellinger, Das Vorkommen des Bence Jonesschen Körpers im Harn bei Tumoren des Knochenmarks und seine diagnostische Bedeutung (Literature), Deut. Arch. f. klin. Med., 1899, 1xii, p. 255; *Dissertation, Königsburg, 1895.

65. Elmer, Some observations on albumoses in urine, Amer. Med., 1906, xi, p. 169.

66. Embden and Knoop, Über das Verhalten des Albumosen in der Darmwand und über das Vorkommen von Albumosen im Blut, Hofmeister's Beitr. f. chem. Phys. u. Path., 1903, iii, p. 20.

67. Emerson, Clinical Diagnosis, 2nd edit., 1908, p. 235.

68. Ewald, Ein chirugisch interessanter Fall von Myelom, Wien klin. Woch., $1897, \mathrm{x}$, p. 169.

*69. Finkelstein, Ein Fall von multiplen myelom, Dissertation, Strassburg, 1900 .

70. Fitz, The significance of albumosuria in medical practice suggested by a fatal case of albumosuric myxoedema treated with thyroid extract, Am. Jr. Med. Sci., 1898, cxvi, p. 30; Trans. Assn. of Amer. Phys., I898, xiii, p. 8. (Good history of development of subject.)

7 I. Flandrin, L'Eclampsie sans Albuminurie et L'Albumosurie, Le Dauphine Med., I900, xxiv, p. 198.

72. Fleischer, Über das Vorkommen des sogenannten Bence Jonesschen Eiweisskörpers in normalen Knochenmark, Virch. Arch., r880, $1 \mathrm{xxx}, \mathrm{p}, 482$.

73. Flora, Sulla malattia di Kahler (mielomi multipli) con albumosuria, Riv. crit. di clin. Med., 1900, i, pp. 797 and 823 .

74. Forrest, The proteids of red marrow, Jr. of Physiol., r894-5, xvii, p. I74.

75. Fränkel, Descriptive Biochemie, 1907, p. 364.

76. Gascard and Devalmont, Sur une albumine thermosoluble dite de Bence Jones, Jr. de Pharm. et de Chim., 1908, xxvii, p. 371.

77. Georges, Sur une variete d'albumine urinaire, Jr. de Pharm. et Chim., 1897, vi (s. 5), p. 326.

78. Gerard, Transformation de l'albumine en Propeptones Dans La Maladie de Bright, Soc. de Biolog., I892-9 (s. 4), p. 398.

79. Gerber, Vienna letter, N. Y. Med. Record, 1909, Ixxvi, p. I Io.

8o. Gerhardt, Ueber die Eiweisstoffe des Harnes, Deut. Arch. $f$. klin. Med., 1869, v, p. 212.

81. Giovine, Albumosuria, Gazz. degli ospedali, Milan, 1907, xxviii, (2), p. 899.

82. Gluzinski and Reichenstein, Myeloma und Leucaemia lymphatica plasmocellularis, Wien klin. Woch., 1906, xix, p. 336; Luow. tygodu Lekar, 1906, i, p. 73. 
83. Grawitz, Maligne Osteomyelitis und sarcomatose erkrankungen des Knochensystems als Befunde bei Fällen von perniciöser Anäemie, Virch. Arch., r879, 1xxvi, p. 353.

84. Grimbert, Sur une albumine thermosoluble dite de Bence Jones, Jr. de Pharm. et de Chim., 1908, xxvii, p. 97.

*85. Grosch, Multiple Myelom des Schädeldaches, Dissertation, Munich, 1906.

86. Grutterink and de Graaf, Ueber die Darstellung einer krystallischen Harnalbumose, Z. f. phys. Chem., I901-2, xxxiv, p. 393.

87. Haack, Ein Beitrag zur experimentellen albumosurie, Arch. f. exp., Path. u. Pharm., 1896-97, xxxviii, p. 175 .

88. Halliburton, Text-book of Chem., Phys. and Path., 1891, p. 783.

89. Halliburton, A discussion of the proteids which may occur in the urine, Trans. Path. Soc. of London, 1900, li, p. 128.

90. Hamburger, Two examples of Bence Jones albumosuria associated with multiple myeloma, Johns Hopkins Hosp. Bull., rgor, xii, p. 38 .

91. Hammer, Primäre sarcomatöse Ostites mit Chronischem Rückfalls fieber, Virch. Arch., 1894, exxxvii, p. 280.

92. Hammarsten, Mandel Text-book of Physiolog. Chemistry, I908, p. 645 .

93. Harbitz, Multiple primaere svulster i bensystem et (mylosarkomer), Norsk. Mag. f. laegevidens Kaben, 1903, lxiv, pp. 1, 89, 169.

94. Harris, A contribution to our knowledge of albumosuria, Am. Jr. Med. Sci., 1896, cxi, p. 557.

95. Haslam, Separation of proteins, Part I, Jr. of Phys., I904-5, xxxii, p. 267; Part II, Deutero-albumose, Jr. of Phys., 1907-8, xxxvi, p. I64.

96. Hawk and Gies, Chemical Studies of osseomucoid with determination of the heat combustion of some connective tissue glucoproteids, Am. Jr. Physiol., rgor, v, p. 387. Gies and collaborators, Biochem. Researches, 1903, i, Reprint No. 3.

97. Hawk and Gies, On the composition and chemical properties of osseoalbumoid with a comparative study of the albumoid of cartilage, Am. Jr. Physiol., 1902, vii, p. 340; Gits and collaborators, Biochem. Researches, 1903, i, Reprint No. 6.

98. Henderson, An investigation into the clinical significance of albumosuria and its value in diagnosis and prognosis, Lancet, I909, I, p. 682 .

99. Heller, Propeptonurie nach Scharlach, Berl. klin. Woch., I889, xxvi, p. 1038 .

Ioo. Herrick and Hektoen, Myeloma, report of a case, Medical News, 1894, 1xv, p. 239.

ror. Herth, Untersuchungen über die Hemialbumose oder das Propepton, Monat. f. Chemie; 1884 , v, p. 266.

102. Herz, Zur Kenntnis des myeloms, Wien med. Woch., 1908, 1viii, pp. I 290, 1359. 
103. Heuck, Zwei Fälle von Leukämie mit Eigenthümlichem Blutresp. Knochenmarkebefund, Virch. Arch., 1879, 1xxviii, p. 475.

104. Hildebrandt, Zur frage nach dem Nährwerth der Albumosen, Z. f. phys. Chem., 1893, xviii, p. 180.

I05. Hirschberg, Zur Kenntniss der osteomalacie und ostitis malacissans, Zeigler's Beit. zur path. Anat., 1889, vi, p. 51 I.

*106. Hirschfeldt, Dissertation, Dorpat, r892.

I07. Hoffman, Ueber Myelomatose, Leukämie und Hodgkinische Krankheit (Literature), Arch. f. klin. Chir., I906, 1xxix, p. 384.

108. Hoffman, Über das Myelom mit besonderer Beruck sichtigung des malignen Plasmoms, Zeigler's Beitr. zur path. Anat., 1904, xxxv, p. 316 (History of 27 cases and literature of pathology of disease).

109. de Holstein, L'Albumosurie comme signe de sarcomes primitifs multiples des os, La Semaine Med., r899, xix, p. 82.

I10. Horsfall-Campbell, Gun shot injury to the leg followed by albumosuria, Lancet, 1903, i, p. I 66.

I I I. Hoppe-Seyler, Thierfelder, Handb. der chem. analyse, Berlin, I909, p. 4 I0.

I12. Hueter, Amyloides mit besonderer Lakalisation in Einem Fall von multiplem Myelom, Muench. med. Woch., I907, liv, p. 8I.

I 13. Hugounenq, Sur l'albumosurie, Jr. de Pharm. et de Chim., I897, cxliv (s. 5), p. 427.

I 14. Hugounenq, L'albumosurie de Bence Jones et Les urines albumosiques, Lyon Med., I901, xcvi, p. 81 .

I15. Hugounenq, Über albumosurie, Chem. Centralblatt, I897, i, p. 1216.

I16. Hugounenq, Sur L'albumosurie, Lyon Med., I897, lxxxiv p. 52 I.

117. Hugounenq, Soc. de Med. de Lyon, 1897.

I18. Hugounenq, Soc. de Med. de Lyon, rgo2.

I19. Huppert, Ueber einen Fall von Albumosurie, Z. f. phys. Chem., I896-7, xxii, p. 500 .

I20. Huppert, Ueber den Noel-Patonschen Eiweisskörper, Central. f. d. med. Wissen., r898, xxxviii, p. $48 \mathrm{I}$.

121. Huppert, Ein Fall von Albumosurie, Prag. med. Woch., 1889, xiv, p. 35 .

122. von Jaksch, Ueber Propeptonuria, Z. f. klin. Med., 1884, viii, p. 216.

123. von Jaksch, Ueber Peptonurie bei acuten Gelenksrheumatismus, Prag. med. Woch., 1881, vi, pp. 6r, 74, 86.

124. von Jaksch, Pneumocystoovarium ein casuistischer Beitrag zur Lehre von der Peptonurie, Prag. med. Woch., I88I, vi, pp. I33 and 144.

125. von Jaksch, Clinical Diagnosis (5th Eng. edit.), 1905, p. 348.

*126. Janowski, Dissertation, Dorpat, 1893.

127. Jellinek, Zur Klinischen Diagnose und pathologischen Anatomie des multiplen Myeloms (Literature), Virch. Arch., 1904, clxxvii, p. 96. 
128. Jochmann and Schumm, Typische Albumosurie bei echter Osteomalacie, Muen. med. Woch., r9or, xlviii, (2), p. 340.

129. Jochmann and Schumm, Zur Kenntnis des Myeloms und der sogenannten Kahlerischen Krankheit (Multiple Myelome), einhergehend mit Bence Jonesscher Albumosurie, Z. f. klin. Med., 1902, xlvi, p. 445 (Literature).

130. Jones, H. Bence, Animal Chemistry, 1850, p. 108.

131. Jones, $H$. Bence, On a new substance occurring in the urine of a patient with Mollities Ossium, Philosoph. Trans. Roy. Soc. of London, 1848, i, p. 55. Proceedings of Roy. Soc. of London, 1843-50, v, p. 673.

132. Jores, Ein Fall von Myelom, Deut. med. Woch., 1906, xxxii, (I) p. 863 .

133. Kahler, Zur Symptomatologie des multiplen Myeloms, Beobachtung von Albumosurie, Prag. med. Woch., 1889, xiv, pp. 33 and 45 .

134. Kalischer, Ein Fall von Ausscheidung des Bence Jonesschen Eiweisskörpers durch den urin (Albumosurie) bei Rippenmyelomen, Deut. med. Woch., rgor, xxvii, p. 54 .

135. Klebs, Allg. Path., 1889, ii, p. 675.

136. Köppen, Ueber Albuminurie und Propeptonurie bei Psychosen, Arch. f. Psychiat., 1889, xx, p. 825.

137. Kraus, Ueber das Vorkommen von Albumosen in normalen Hundeblut, Z. f. exp. Path. und Ther., r9o6, iii, p. 52.

138. Krehl and Matthes, Ueber febrile Albumosurie, Deut. Arch. f. klin. Med., 1894-95, liv, p. 501.

139. Kudrewetzky, Zur Lehre von der durch Wirbelsäulen tumoren Beduigten Compressions erkrankung des Rückenmarkes, $Z$. f . Heilkunde, r892, xiii, p. 300 .

140. Kühne, Albumosen und Peptone, Verhand. des Naturhist. Med. Ver. $z u$ Heidelberg (n. f.), 1881-86, iii, p. 286.

141. Kühne, Ueber Hemialbumose im Harn, Z. f. Biol. (n. f.), I883, i, p. 159.

142. Kühne and Chittenden, Ueber die nächsten Spalttungs producte der Eiweisskörper, Z. f. Biol. (n. f.), 1883, i, p. 159.

143. Kühne and Chittenden, Ueber Albumosen, Z. f. Biol. (n. f.), I884, ii, p. II.

144. Kühne and Chittenden, Globulin u. Globulosen, Z.f. Biol. (n. f.), I886, iv, p. 409 .

145. Langedorff and Mommsen, Beitrag zur Kenntniss der Osteomalacia, Virch. Arch., 1877, 1xix, p. 452.

146. Langstein, Über das Vorkommen von Albumosen im Blut, Hofmeister's Beit. f. ch. Phys. u. Path., 1903, iii, p. 373.

147. Lassar, Ueber den Zusammenhang von Hautresorption und Albuminurie, Virch. Arch., 1879, 1xxvii, p. 157.

*148. Lazarus, Multiple sarcoma mit perniciöser, Anäemie und Gleichzeitiger Leukämie, Dissertation, Berlin, 1890. 
149. Leick, Beitrag zur Lehre von der Albumosurie, Deut. med. Woch., 1896, xxii, p. 22.

150. Lepine, Sur une forme particuliere de crises gastriques dans l'uremie, Bull. de la Soc. Med. des Hosp. de Lyon, 1902, i, p. 185.

151. Levene, The cleavage products of proteose, Jr. Biolog. Chem., I905, i, p. 45.

152. Lindemann, Zur Kenntniss des Bence Jonesschen Eiweisskörpers, Deut. Arch. f. klin. Med., 1904, cxxxi, p. II4.

153. Loeb, Ueber einige seltenere Complicationen des Scharlachs (Propeptonurie, Tetanie, Aphasie, Ataxie), Arch. f. Kinderheilk., 1889, x, p. 212.

I54. Loeb, 'Propeptonurie ein häufiger Befund bei Masern, Centr. f. klin. Med., 1889, x, p. $26 \mathrm{r}$.

155. Loeb, Propeptonurie bei Masern, Arch. f. Kinderheilk., 1888, ix, p. 53 .

156. Loewy and Richter, Zur Chemie des Blutes, Berl. klin. Woch., I897, xxxiv, p. 1028 .

157. Lubarsch, Zur Myelom frage, Virch. Arch., I906, clxxxiv, p. 2 I 3.

158. MacCallum, W. G., A case of multiple myeloma, Jr. of Exp. Med., I90I-5, vi, p. 53 .

159. MacIntyre, Case of Mollities and Fragilitas ossium accompanied with urine strongly charged with animal matter, Med. Chir. Trans., 1850, xxxiii, p. 2 I I.

160. Maget, Nouvelle Reaction de l'urine traité pa l'ethersulphurique et Revelant la presence d'albumoses Dans l'urine, Lyon Med., I900, xciii, p. 20.

161. Magnus-Levy, Ueber den Bence Jonesschen Eiweisskörper, Congress f. innere Med., I900, p. 496; Z. f. phys. Chemie, I900, xxx, p. 200. 162. Maixner, Ueber eine neue Form der Peptonurie, Z. f. klin. Med., 1884, viii, p. 234.

163. Mann, Chemistry of proteids, 1906, p. 369.

164. Marchand, Allgem. Sarkomat des Skellets, Berl. klin. Woch., I886, xxiii, p. 487 .

165. Marckwald, Ein Fall von multiplem intravasculärem endotheliom in den gesammten Knochen des Skelets (Myelom Angiosarcom), Virch. Arch., 1895, cxli, p. I 28.

166. Martin, Report on the pathology of the proteids of the body, Brit. Med. Jr., I891, i, p. 159.

167. Matthes, Zur chemie des leukämischen Blutes, Berl klin.

Woch., 1894, xxxi, pp. 531 and 556.

168. Matthes, Ueber Eiweisskörper im Urine bei Osteomalacie, Cong. f. Innere Med. 1896 , xiv, p. 476.

169. Meltzer, Myelopathic Albumosuria, Med. Record, 1904, lxv, p. 989 .

170. Menne, Zur Kenntniss der Myelomzellen (Literature), Virch. Arch., 1906, clxxxiii, p. I15. 
171. Milroy, A contribution to our knowledge of a rare form of albumose occurring in the urine, Jr. Path. and Bact., I901, vii, p. 95.

172. Moffatt, Myelopathic Albumosuria (Literature), Lancet, 1905, i, p. 207.

173. Moitessier, Sur un cas D'Albumosurie de Bence Jones, Montpellier Med., 1904, xix, p. 417.

174. Moitessier, Sur La Nature de la substance albuminoide de Bence Jones, Seanc. et Mem. de la Soc. de Biol., I904, 1vii, p. 498.

175. Morawitz and Dietschy, Über Albumosurie nebst Bermerkungen über das Vorkommen von Albumosen im Blut, Arch. f. exp. Path. u. Pharm., 1905-6, liv, p. 88.

176. Mosenthal and Gies, Proteosuria, Amer. Medicine, 1902, iii, p. 387; Gies and collaborators, Biochem. Researches, r903, i, Reprint No. 33 .

177. Müller, Zur Leukämie Frage, Deut. Arch. f. klin. Med., 189r, xlviii, p. 47.

I78. Munk, Albumose and albumosuria, Eulenberg's Real. Encyl. der Gesamt. Heilk. (3rd edit.), i, p. 403.

179. Musy, Des Rapports Entre La Fievre et l'Albumosurie, Soc. de Biol., I898, v (s. 10), p. 875 .

I80. Nasse, Ueber einen Fall von multiplem primären Sarkom des Periostes, Virch. Arch., I883, xciv, p. 461 .

181. Naunyn, Mittheilung von einem Fall von Albumosurie, Deut. med. Woch., r898, xxiv, p. 217.

182. Neubauer and Vogel, Huppert, Analyse des Harnes, 1898, i, p. 875 .

183. Neumeister, Ueber die Reactionen der Albumosurie und peptone, Z. f. Biol. (n. f.), viii, p. 325 .

184. Neumeister, Bemerkungen zur Chemie der albumosen und Peptone, Z. f. Biol. (n. f.), vi, p. 267.

185. Neumeister, Lehr d. phys. Chem., Jena, 1897, p. 804.

186. Neumeister, Ueber die Einführung der Albumose und Peptone in der Organismus, Zeit. f. Biol. (n. f.), vi, p. 272.

I87. Neumeister, Zur Kenntnis der Albumosen, Z. f. Biol. (n. f.), I886, v, pp. $38 \mathrm{I}$ and $40 \mathrm{I}$.

188. Nothnagel, Ueber eine eigenthümliche perniciöse Knochenerkrankung (Lymphadenia ossium), Festschrift, $R$. Virchow, I891, ii, p. 155. 189. Odenius, Fall af myelo-sarcoma; myeloma multiplex angiectaticum ossis ischii, Nordiski Med. Arkiv., 1894, iv, No. 21 , p.i.

190. Ogden, Examination of urine, 1903, p. 136.

I91. Orum, El Tilfaelde af Bence Jones Albumosuri, Ugeskrift $f$. Laeger, 1904, No. xxiv, p. 559.

192. Ottenberg and Gies, On the fate of elastose after its subcutaneous or intraperitoneal injection, a preliminary inquiry into the nature and origin of Bence Jones's protein, Proc. Soc. Exp. Biol. and Med., I907, iv, p. I6r. 
193. Paltauf, Neubildungen-Lymphosarkom (Lymphosarcomatose, Pseudoleukamie, Myelom, Chlorom) (Literature), Lubarsch $u$. Ostertag, Erg. d. Allg. Path., 1896, iii, p. 652.

194. Pappenheim, Über Begriff des Myelom, seine Klassi fizizierung im nosologischen System der Erkrankungen des hämotopoetischen Apparates und seine Beziehungen $\mathrm{zu}$ verwandten Krankheits prozessen, Folia hematology, Supplement, 1907, iv, p. 215.

195. Pappenheim, Wie verhalten sich die Unnaschen Plasmazellen zu Lymphocyten, Virch. Arch., 1901, clxvi, p. 424.

196. Patein, Les albumines aceto-solubles et l'albumosurie de Bence Jones, Jr. de Pharm. et de Chim., 1904, xix (6 s.), p. 580; Jr. de Pharm. et de Chim., r904, xx, p. 12; Jr. de Pharm. et de Chim., r904, xx, p. 49.

197. Patein and Michel, Contribution a l'étude de l'albumosurie de Bence Jones, Seanc. et Mem. Soc. de Biol., r904, 1vi, p. 889.

198. Paton, On a crystalline globulin occurring in human urine, Proc. Roy. Soc. of Edinburg, xix, p. 102.

199. Permin, Ueber Myelom (Literature), Virch. Arch., 1907, clxxxix, p. 439 .

200. Permin, Om myelom, Hospitals tidende., I907, xv, pp. I24I and 1265 .

201. Pertik, Ueber multiple Myelome, Pester Medizin Chir. Press, I888, xxiv, p. 507 .

202. Piery, Contribution a la valeur semeiologique des albumoses sur une pietendue propriëte specifique des albumoses. Leur coagulation par L'ether, Lyon Med., 1903, ci, p. 554.

203. Pick, Zur Kenntniss der peptischen Spaltungsprodukte des Fibrins, Z. f. physiol. Chem., I899, xxviii, p. 219 ; Beiträge für chem. Phys. u. Path., 1902, ii, p. 48 I.

204. Pick and Spiro, Ueber gerinnungshemmende Agentien im Organismus höherer Wirbelthiere, Z. f. phys. Chemie, r900-I, xxxi, p. 235 .

205. Posner, Ueber Propeptonurie, Berl. klin. Woch., I888, xxv, p. 417 .

206. Quackenboss and Verhoeff, Multiple myeloma with involvement of the orbit, Jr. Med. Research, I906, X, p. 261.

207. Raschkes, Ein Fall von seniler Osteomalacie mit Albumosurie, Prag. med. Woch., 1894, xix, p. 649.

208. Reach, Ein Beitrag zur Kenntniss der Bence Jonesschen Albuminurie, Deut. Arch. f. klin. Med., r905, 1xxxii, p. 390.

209. Ribbert, Über das Myelom, Central. f. Allg. Path., I904, xv, p. 337 .

2 10. Ribbert, Lehr. der Allg. Path., r90r, p. 50 r.

*21 I. Ribbinik, Dissertation, Amsterdam, 1892.

212. Ribbinik, Ein Fall von Albumosurie. Abstract Maly's Jahr.d Tierchemie, 1892, xxii, p. 525 . 
213. Richards and Gies, Chemical studies of elastin, mucoid, and other proteids in elastic tissue with some notes on ligament extractives, Am. Jr. Phys., 1902, vii, p. 93; Gies and collaborators, Biochem. Researches, I903, i, Reprint No. 4.

214. Rosin, Über einen Eigenartigen Eiweisskörper im Harn und seine diagnostische Bedeutung, Allg. Med. Central-Zeitung, 1897, 1xvi, p. 1132; Berl. klin. Woch., 1897, xxxiv, p. 1044.

215. Rostoski, Albumosurie und Peptonurie, Deut.med. Woch., rgor, xxvii, p. 224; Muen. med. Woch., I901, xlviii, p. III5; Sitz. Bericht der Physik-Med. Gesell. zu Wurzburg, rgor, pp. 31 and 33.

216. Rostoski, Ueber den Werth der Präzipitine als Unterscheidungsmittel für Eiweisskörper, Muench med. Woch., 1902, xlix (1), p. 740.

21 7. Rostoski, Ubber Albumosen und Pepton präcipitine, Sitz. Bericht der physik. Mied. Gesell. zu Wurzburg, 1902, p. 82.

218. Runeberg, Ein Fall von medulläre Pseudoleukamie, Deut. Arch. f. klin. Med., I883, xxxiii, p. 629.

219. Rünike, Ein Geval von Albumosurie, Nederl. Tijdschrift voor Geneeskund, 1897, xxxiii (1), p. 628.

220. Rustizky, Multiples Myelom, Deut. Z. f. Chir., 1873, iii, p. 162.

221. Sacconaghi, Ueber die Präcipitine der Verdauungs produkte, Z. f. klin. Med., 1903-4, li, p. 187.

222. Sahli, Kinnicutt, Diagnostic methods, I907, p. 466.

223. Salkowski, Ueber die Wirksamkeit erhitzer Fermente den Begriff des Peptons und die Hemialbumose (Kühnes), Virch. Arch., r88I, 1xxxi, p. 552 .

224. Salkowski, Ueber den Nachweis des Peptons (Albumosen) im Harn und die Darstellung des urobilins, Berl. klin. Woch., 189r, xxxiv, p. 353 .

225. Salkowski, Botkin and Heyman, Ueber die Wirkung der Albumosen und des Peptons, Central. f. d. med. Wissen., 1895, xxxiii, p. 545 .

226. Salkowski and Leube, Die Lehre von Harn, 1882, p. 210.

227. Saltykow, Beitrag zur Kenntnis des Myeloms, Virch. Arch., 1903, clxxiii, p. 53 I.

228. Scheele und Herxheimer, Ueber einen bemerkenswerthen Fall von multiplem Myelom (sogenannter Kahler'scher Krankheit), $Z$. f. klin. Med., 1904, liv, p. 57.

229. Schönenberger, Über osteomalacie mit multiplen RiesenzellSarcomen und multiplen Fracturen, Virch. Arch., 190r, clxv, p. 189.

23o. Schmidt, Résumé and bibliography of pathology of bone, Lubarsch u. Ostertags Erg. der Allg. Path., 1897, iv, p. 531 ; 1898, v, p. 895.

23I. Schmidt-Mülheim, Beiträg zur Kenntniss des Peptons und seiner physiologischen Bedeutung, Arch. f. Anat. u. Phys., 1880; Phys. Abtheil, p. 33 . 
232. Schultess, Die Beziehungen zwischen albumosurie und Fieber, Deut. Arch. f. klin. Med., I896-7, 1viii, p. 325.

233. Schultess, Weitere Erfahrungen über die Beziehungen zwischen Fieber und Albumosurie, Deut. Arch. f. klin. Med., I897-8, 1x, p. 55.

234. Schwarz, Ein Fall von Leukämie mit Riesenzellenembolie und allgemeiner Osteosklerose, Z. f. Heilk., (Path. Anat.), I90I (n. f.), ii, p. 294.

235. Seegelken, Ueber multiples Myelom und Stoffwechseluntersuchungen bei demselben, Deut. Arch. f. klin. Med., 1897, lviii, pp. 126 and 276.

236. Senator, Asthenische Lähmung Albumosurie und multiple Myelome, Berl. klin. Woch., I899, xxxvi, p. I6r.

237. Senator, Traité de l'Albuminurie, r891, p. 17, Paris.

238. Senator, The clinical significance of albumosuria, Internat. Clin., 1905, (14th s.), iv, p. 85 .

239. Sens, Über Albumosurie u. Peptonurie, Dissert. Berlin, r89I; Abstract Central f. d. med. Wissen., 1892, xxx, p. 825 .

240. Sicard, L'Albumosuria, La Riforma Medica, I9or, iv, p. 344.

241. Sicard, L'Albumosurie et les reáctions de Bence Jones et de Jacquemet, La Presse Med., Igor, ix (2), p. 2 I 3.

242. Sicuriani, Contribute allo studio chimico dell' albumosuria

(Da un caso di morbo di Kahler), La Reformi Med., 1908, xxiv, p. 425.

243. Simon, Observations on the nature of the Bence Jones albumin (Record of 22 cases), Am. Jr. Med. Sci., 1902, 1xxiii, p. 939.

244. Simon, Text-book of physiol. Chem., r907, p. 305.

245. Simon, Clinical diagnosis, r907, pp. 456 and $47 \mathrm{r}$.

246. Simmonds, Ueber multiples Myelom, Muen. med. W'och., I906, liii (2), p. 1438 .

247. Solly, Pathology of Mollities Ossium with cases, Med. Chir. Trans., 1884, xxvii, p. 435 .

$*_{24}$. Solon, D'Albumosurie.

*249. Sorge, Über einen Fall von Bence Jonesschen Körper bei Erkrankung des Rumpfskelletts, Dissertation, Jena, 1900.

250. Spaeth, Die Chem. u. Mikros. untersuch. des Harnes, 1903, p. 334.

$*_{25}$ r. Spiegelberg, Beiträge zur Kenntniss des multipel auftretenden Knochensarcome, Dissertation, Frankfurt, 1894 .

*252. Stadelman, Peptonuria, Dissertation, Wiesbaden, 1894.

253. Sternberg, Primärerkrankungen des lymphatischen und hämotopoetischen apparates, normale und pathologische Morphologie des Blutes, Lubarsch und Ostertag, Erg. der Allg. Path., 1903, ix (2), p. 449 (Myelom).

254. Sternberg, Nothnagel's Spec. Path. u. Ther., 1899, 7, ii, Abth. 2, p. 56 (Literature).

255. Sternberg, Beitrag zur Myelomfrage, Verhand. der Deut. Path. Gesell., 1903, p. 34.

256. Sternberg, Zur Kenntniss des Myeloms, Z. f. Heilk., 1904 (n. s.), v, p. 89 . 
*257. Stoffiezen, Dissertation, Dorpat, $\mathbf{1 8 9 1 .}$

258. Stokvis, Over Hemialbumosurie, Nederl. Tijdschrift v. Geneesk., 1891, ii, p. 136; Abstr. Maly's Jahr. d. Tierchem., I891, xxi, p. 4I2.

259. Straub, Beitrag zur Kenntniss der Hemialbumose, Nederl. Tij. voor Geness, 1884, pp. 173, 189, 219, 252, 281. Abstr. Maly's Jahr. d. Tierchem., 1884, xiv, p. 28.

*260. Strub, Dissertation, Erlangen, 1905.

*26r. Sudhoff, Ueber das primäre multiple Carcinom des KnochenSystems, Dissertation, Erlangen, $\mathbf{1 8 7 5}$.

*262. Sussman, Ueber einen Fall von multiple Myelombildung mit hochgradiger Albumosurie, Dissertation, Berlin, 1897.

263. Taylor, Contribution to the pathology of albumosuria, Trans. Path. Soc. of Phila., 1895-97, xviii, p. 313.

264. Ter-Grigoriantz, Ueber Hemialbumosurie, Z. f. physiol. Chem., 1882, vi, p. 537.

265. Thomas, A case of myeloma of the spine with compression of the cord, Boston Med. and Surg. Jr., I90r, cxlv, p. 367.

266. Thompson, Contribution to the study of peptones when injected into the circulation, Part I, Jr. of Physiol., I896, xx, p. 455; Part II, Jr. of Physiol., 1899, xxiv, p. 374 (The influence of purified pepton and of proteoses on blood coagulation and the vaso-motor system); Part III, Jr. of Physiol., 1899, xxiv, p. 396 (The local vascular influences of peptones and proteoses effects on the intestinal and renal arteries); Part IV, Jr. of Physiol., I900, xxv, p. I (Effects on splenic, hepatic, and limb districts); Part V, Jr. of Physiol., 1900, xxv, p. I79 (Influence of peptones and albumoses in urinary secretion).

267. Thompson, Effects of peptones and albumoses on the kidney, Brit. Med. Jr., 1898, i, p. 695.

268. Thormählen, Ueber ein eigenthümliche Eiweissart im menschlichen Urin, Virch. Arch., 1887, cviii, p. 322.

269. Tschistovitsch and Kolesnikowa, Diffuse myelom der knochen mit Kalkablagerungen in den Lungen und in anderen organen, Russk. Wratsch., 1908, 7 (2), pp. 1277, 1318; Virch. Arch., 1909, cxcvii, p. II2. Abstract in Folia hematol., 1909, vii, p. 150.

270. Umber, Demonstration des Bence Jonesschen Eiweisskörpers, Muench. med. Woch., 1907, liv (1), p. $8 \mathrm{rr}$.

271. Umber, Die Spaltung des Krystallinischen Eier- und serumalbumins sowie des serum globulins durch Pepsinverdauung, Z. f. phys. Chem., $1898, \mathrm{xxv}$, p. 258.

272. Underhill, New experiments on the physiological action of proteoses, Am. Jr. of Physiol., 1903, ix, p. 345 .

273. Ury and Lilienthal, Uber Albumosuria bei Magen, Darmerkrankungen spezielle Carcinomen, Arch. f. Verdauungs Krank., 1905, xi, p. 72.

274. Verco, A case of myelopathic albumosuria, Austral. Med. Gaz., 1903, xxii, p. 185 . 
275. Verebelely, Über das Myelom, Beitr. zur. klin. Chir., I906, xlviii, p. 614 .

276. Vickery, A case of albumosuria of the pernicious anaemia type, Phila. Med. Jr., I902, x, p. 155.

277. Vidal, Note sur un cas a'albumosurie, Soc. de Biol., 1898 (10 s), v, p. 991 .

278. Vignard and Gallavardin, Du Myéloma multiple des Os Avec Albumosurie, Rev. de Chir., 1903, xxvii, p. 91.

279. Virchow, Die krank. Geschwülste, I864, ii, p. 57.

280. Virchow, Über parenchymatöse Entzündung, Virch. Arch., I852, iv, p. 309.

281. Voit, Uber das Bence Jonessche Eiweiss, Festschrift, J. Rosenthal, Leipsic, I906, ii, p. II 8 .

282. Voit and Salvendi, Zur Kenntnis der Bence Jonesschen albuminurie, Muench. med. Woch., 1904, li (2), p. I281.

283. Waldstein, Ein Fall von progressiver Anämie und darauf folgender Leucocythämie mit Knochenmarkenkrankung und Einem sogenannten Chlorom. (Chlorolymphom), Virch. Arch., I883, xci, p. 12.

284. Weber, F., General lymphadenomastosis of bones, one form of multiple myeloma, Jr. Path. and Bact., 1898, v. p. 59.

285. Weber, H., Mollities ossium, doubtful whether carcinomatous or syphilitic, Trans. Path. Soc. of London, 1867, xviii, p. 206.

286. Weber, F., Multiple myeloma (Myelomatosis) with Bence Jones proteid in the urine, Jr. of Path. and Bact., 1904, ix, p. 172 (List of 28 cases to that date).

287. Weber, A case of multiple myeloma with Bence Jones proteid in the urine and a summary of published cases of Bence Jones albumosuria with a report on the chemical pathology by Hutchison and Macleod, Med.-Chir. Trans., 1903, 1xxxiii, p. 395; Am. Jr. Med. Sci., 1903, cxxvi, p. 644 .

288. Weber, A case of multiple myeloma with Bence Jones proteid in the urine, Lancet, I903, i, p. 73I.

289. Weber and Blendiger, A note on "mulberry" cells and clusters of eosinophile spherules probably a form of "Russel's fuchsine bodies" in the walls of a chronic cerebral abscess and in a case of multiple myeloma, Jr. of Path. and Bact., 1906-7, xi, p. 59.

290. Weber and Legingham, A note on the histology of a case of myelomatosis (multiple myeloma) with Bence Jones protein in the urine, Proc. of the Royal Soc. of Medicine, Path. Sect., I909, II, p. 193; Folia hematol., 1909, viii, p. 14 .

291. Weinberger, Case of chloroma in which Bence Jones body was found, Gesell. f. innere Med. in Wien, Wien. klin. Woch., I903, xvi, p. 461 .

292. Wells, Chemical Pathology, r907, p. 427.

293. Wells, Experimental cirrhosis of the liver in chronic albumose intoxication, Proc. Path. Soc. of Chicago, rgor-3, v, p. 240. 
294. Westmorland, Case of hemialbumosuria, Lancet, I892, i, p. I 240.

295. Wieland, Studien über das primär multipel auftretende Lymphosarcom der Knochen, Virch. Arch., I901, clxvi, p. I03.

*296. Wieland, Primär multiple Sarcome der Knochen, Dissertation, Basel, 1893 .

297. Winkler, Das Myelom in anatomischer und Klinischer Beziehung, Virch. Arch., 1900, clxi, p. 253.

298. Wohlgemuth, Chemische Untersuchung über menschliches Knochenmark bei verscheiden patholog. affektionen, Arb. a/d. Path. Insti. zu Berlin, I906, p. 627.

299. Wood, Chemical and microscopical diagnosis, 1905, p. 509.

30o. Wright, A case of multiple myeloma, Jr. Bost. Soc. of Med. Sci., 1899-1900, iv, p. 695; Johns Hopkins Hosp. Report, 1900, ix, p. 359; Trans. of Assn. of Amer. Phys., 1900, xv, p. 137.

301. Yarrow, The albumoses, their clinical significance viewed from a modern standpoint, Amer. Medicine, r903, v, p. 452.

302. Zahn, Ueber das Multiple Myelom, seine Stellung im Onkologischen System und seine Beziehung zur Anaemia lymphatica, Deut. Z. f. Chir., 1885 , $\mathbf{x x i i}$, p. $\mathrm{x}$.

303. Zeehuisen, Ein Fall von Albumosurie, Vg'l. ned. Tijdscher voor Geneeskunde, 1893, i, p. 829; Abstr. in Maly's Jahr. d. Tierchem., 1893, xxiii, p. 577.

304. Zuelzer, Ueber experimentelle Bence Jonessche Albumosurie, Berl. klin. Woch., 1900, xxxvii, p. 894.

305. Zuminger, Multiple myeloma, Amer. Medicine, 1904, vii, p. 637.

306. Zunz, Contribution à l'etude des Proteoses, Arch. Internat. de Physiol., 1907, v, p. 245.

\section{References not verified on account of non-accessibility.}

Grall, Union Pharmaceutique, 1897, p. 578.

Hamburger, Lab. d. Utrecht, 188, vi (3 s.), 10, p. 64.

Hann, Jr. f. prakt. Aertze, Frankfurt, 1897, vi, pp. 8 1 1, 1083, 1107.

Hugounenq, Chimique, Phys. et Path., 1897, p. 526.

Jacquemet, Soc. de Med. de L'Isere, July, r898; June, Nov. and Dec., I900; May and Dec., I901.

Jacquemet, Dauphine Med., No. 7, 1898.

Hospitalstunde, Copenhagen, 1908.

Stokvis, Maandblad der sectie voor Naturswerteinschaft, 1872, vi.

Bonordi, $R$ rst Lomb. di sc. e. leit Rendic Milano, 1903, xxxvi (2 s.), p. 839 .

Turck, Mitt. der Gesell. für Inn. Med. in Wien, 1903, xxxii.

Trans. 8th Congress di Med., 1897.

Z. f. Orthoped. Chir., 1908, xxii, p. 2221.

Medelselen Fra Rigs Hospital, Path. Anat. Instit., I902, v 
Mémoire della $R$ Acad. del la Scienza di Torino, 1902.

Soc. de Med. de l'Isere, 13 th and 2oth Jan., 1899; 23rd May and 19th Dec., 1899.

Latabut, Dauphine Med., 1899, No. 1, No. 2 and No. 6; Dauphine Med., 1900, No. 2 and No. 9; Dauphine Med., 1901, No. 6; Province Med., 1899, 16th and 23rd Dec.; Soc. de Med. de Grenoble, 1900, 13th Nov.; Soc. de Med. de Grenoble, 1901, 21st May.

Deart es physik. gyozyiton-Budapest, 1905, xvii.

Arch. Ital. di Med. Int., 1900, iii, No. 1 and 2.

Ann. di Chim. et de farm., 4-5, p. 193.

Mörner, Skand. Arch., 1895, vi, pp. 374 and 379.

Patein, Bull. de Soc. pharmacol., 1904, ix, p. 339.

Dechaunne, École de pharm., Lyon, 1903.

Fittipaldi, N. Nv. clin. Therap. Napoli, 1905, viii, p. 236; Ann. d. Chem. u. Pharm., lxi, p. 329; Ann. d. Chem. u. Pharm., lxvii, p. 97.

Müller, Verh. d. Natur. gez. zu Basel, 1901, xiii, p. 308.

Chiari, Verrin deut. Arate im Prag., Oct. 12, 1883.

Considerable time and great care were expended in working up this bibliography. The author was very much surprised by the laxity of some writers. Twenty-six references were found to be incorrect. Four of these references were ultimately traced to their sources and it was found that these mistakes were chiefly typographical errors, but, alas, none of the remaining twenty-two references could be found even after a diligent search through all the files of the periodicals mentioned and through journals whose titles were nearly similar to the ones indicated. 


\section{BIOGRAPHICAL.}

Jacob Rosenbloom was born at Braddock, Penn., Feb. 25 , r884. He received an elementary and high school education at North Braddock, Penn., and graduated from the Western University of Pennsylvania in 1905, with the degree of B.S. The title of his graduation thesis was "Colorimetric Determination of Tungsten." He has served as chemist at the East Pittsburg Gas Works, East Pittsburg, Pa. (summer, 1903); chemist at the Edgar Thompson Steel Works, Bessemer, Pa. (summer, 1904); chemist at the Duquesne Steel Works, Duquesne, Pa. (summer, 1905).

During the academic years $1905^{-9}$ he has been in attendance at Columbia University as a candidate for the degree of Doctor of Medicine and of Doctor of Philosophy. During the summer of 1907 he did pathological work at the West Penn. Hospital, Pittsburg, $\mathrm{Pa}$. , and, in the summer of 1908 , he equipped a chemical laboratory for metabolic urinary work at the West Penn. Hospital, Pittsburg, Pa.

He has been appointed assistant in biological chemistry in Columbia University for the year 1909-'ro.

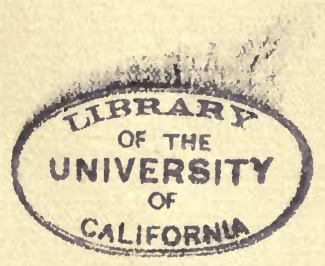




\section{PUBLICATION.}

Some azolitmin compounds of mucoids, nucleoproteins and other proteins, with exhibition of products (with William J. Gies.) A preliminary report. Proceedings of the American Society of Biological Chemists, 1907, i, p. 48; also Journal of Biological Chemistry, 1907, iii, p. 39. 



\section{UNIVERSTTY OF CALIFORNIA LIBRARY,
BERKELEY}

\section{THIS BOOK IS DUE ON THE LAST DATE \\ STAMPED BELOW}

\section{Books not returned}

$50 \mathrm{c}$ per volume after the thime are subject to a fine of $\$ 1.00$ per volume after third day overdue, increa of demand may be renewed the sixth day. Bookseasing expiration of loan period.

\section{DEC 211923}



